\title{
EMPLOYMENT AND LAND-USE IMPACTS \\ OF RESOURCE PROGRAM ELEMENTS
}
S. A. Shankle
M. C. Baechler
D. W. Blond in
S. E. Grover

March 1992

\begin{abstract}
Prepared for Bonneville Power Administration under a Related Services Agreement with the U.S. Department of Energy Contract DE-AC06-76RLO 1830
\end{abstract}

Pacific Northwest Laboratory Richland, Washington 99352 

The Pacific Northwest Laboratory (PNL) evaluated several power resource alternatives under consideration by the Bonneville Power Administration in its Resource Program Environmental Impact Statement (RPEIS). The purpose of this evaluation was to determine the potential impacts of each alternative in terms of 1 and use and employment.

We reviewed the literature that describes land-use and employment impacts to derive estimates of each type of effect. These estimates were scaled to a per-megawatt basis for use as multipliers in the RPEIS analysis. Multipliers for employment were taken from the literature and developed from power plant capital cost estimates. Land-use multipliers were taken from the 1 iterature or estimated from existing plants. In this report we compared information sources and estimates to develop the most applicable multipliers.

Table S.1 shows employment levels required (in terms of employee years per MW of plant capacity) for the construction and operation phases of each energy-generating resource alternative analyzed. Table 5.2 shows the amounts of land required (in terms of acres per MW capacity) for the construction and operation phases of each energy-generating resource alternative analyzed. 
TABLE S.1. Employment Impacts Summary

Resource

Pulverized coal

Atmospheric fluidized bed coal

Coal gasification

Cogeneration (overall average)

Cogeneration (wood-fired)

Cogeneration (municipal solid waste)

Combined cycle combustion turbine

Geothermal

Hydroelectric (overall average)

Hydro efficiency improvements

Small hydro 1

Small hydro 2

Small hydro 3

Small hydro 4

Solar

Wind

Nuclear

Conservation (overall average)

Conservation (res. space heat: Ex. SF)

Conservation (res, space heat: Ex. MF)

Conservation (res. space heat: New SF)

Conservation (res. space heat: New MF)

Conservation (res. space heat: New man.)

Conservation (res. appl.: refrigerators)

Conservation (res. appl.: freezers)

Conservation (res. appl.: water heaters)

Conservation (com: ex bldgs disc.)

Conservation (com: ex bldgs lost opp.)

Conservation (com: new bldgs lost opp.)

Conservation (industrial)

Conservation (agricultural)

$\begin{array}{cc}\text { Construction } & \text { Operations } \\ \text { Employment } & \text { Employment } \\ \text { (employee years } & \text { (employees per } \\ \text { Der MW capacity) } & \text { MW capacity) }\end{array}$

$4.7 \quad 0.5$

$5.1 \quad 0.7$

$5.7 \quad 0.9$

$15.1 \quad 4.5$

$9.6 \quad 4.5^{(a)}$

$24.1 \quad 4.5$

$1.4 \quad 0.1$

$4.1 \quad 0.3$

$9.3 \quad 0.3$

$4.9 \quad$ None

$8.3 \quad 0.2$

$10.4 \quad 0.2$

$14.3 \quad 0.3$

$17.3 \quad 0.4$

$19.6 \quad 0.4$

$1.9 \quad 0.4$

$1.8 \quad 0.9$

41.7 None

77.9 None

74.4 None

79.2 None

81.2 None

55.0 None

18.7 None

23.3 None

18.1 None

30.2 None

20.2 None

19.6 None

21.9 None

22.5 None

(a) Estimate is for municipal solid waste plant. No data for wood-fired cogeneration operations employment were found. 
TABLE S.2. Land-Use Impacts Summary

Resource

Pulverized coal

Atmospheric fluidized bed coal

Coal gasification

Cogeneration (overall average)

Cogeneration (wood-fired)

Cogeneration (municipal solid waste)

Combined cycle combustion turbine

Geothermal

Hydroelectric (overall average)

Hydro efficiency improvements

Small hydro 1

Small hydro 2

Smal 1 hydro 3

Small hydro 4

Solar

Wind

Nuclear

Conservation (overall average)

Conservation (res. space heat: Ex. SF)

Conservation (res. space heat: Ex. MF)

Conservation (res. space heat: New SF)

Conservation (res. space heat: New MF)

Conservation (res. space heat: New man.)

Conservation (res. appl.: Refrigerators)

Conservation (res, appl.: Freezers)

Conservation (res. appl.: Water heaters)

Conservation (com: ex bldgs disc.)

Conservation (com: ex bldgs lost opp.)

Conservation (com: new bldgs lost opp.)

Conservation (industrial)

Conservation (agricultural)
Construction

Land Use

(acres per

Mul capacityl
Operations

Land Use

(acres per

MW capacity)

$\begin{array}{ll}1.0 & 0.2 \\ 1.5 & 0.2 \\ 0.6 & 0.2 \\ 1.7 & N Q \\ 2.1 & N Q \\ 1.6 & N Q \\ 0.1 & N Q \\ 0.2 & N Q \\ \text { NQ } & N Q \\ \text { None } & \text { None } \\ \text { NQ } & \text { NQ } \\ \text { NQ } & \text { NQ } \\ \text { NQ } & \text { NQ } \\ \text { NQ } & \text { NQ } \\ 3.0 & \text { None } \\ 5.9 & \text { None } \\ 1.74 & \text { NQ } \\ \text { None } & \text { None } \\ \text { None } & \text { None } \\ \text { None } & \text { None } \\ \text { None } & \text { None } \\ \text { None } & \text { None } \\ \text { None } & \text { None } \\ \text { None } & \text { None } \\ \text { None } & \text { None } \\ \text { None } & \text { None } \\ \text { None } & \text { None } \\ \text { None } & \text { None } \\ \text { None } & \text { None } \\ \text { None } & \text { None } \\ \text { None } & \text { None } \\ & \end{array}$

NQ $=$ Not quantified. 



\section{CONTENTS}

SUMMARY

1.0 INTRODUCTION

2.0 ANALYSIS METHODOLOGY

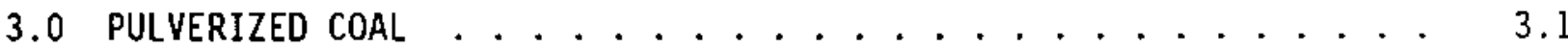

3.1 CONSTRUCTION . . . . . . . . . . . . . . . . . . 3.1

3.1.1 Schedule and/or Duration ............ 3.1

3.1.2 Direct Employment Schedule ............. 3.3

3.1.3 Skill Mix of Construction Employees . . . . . . . 3.5

3.1.4 Employment Multiplier(s) . . . . . . . . 3.9

3.1 .5 Construction Land-Use Impacts ......... . 3.10

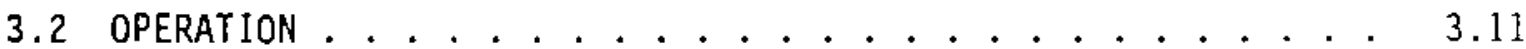

3.2.1 Main Facility Direct Employment . . . . . . . 3.12

3.2.2 Coal Mine Direct Employment . . . . . . . . 3.14

3.2.3 Employment Multiplier(s) . . . . . . . . . . . . 3.14

3.2.4 Operation Land-Use Impacts............. . 3.14

4.0 ATMOSPHERIC FLUIOIZEO BEO COAL . . . . . . . . . . . . . . 4.1

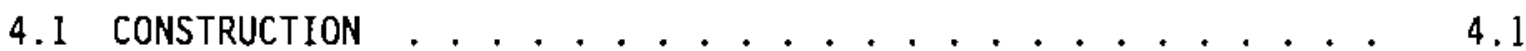

4.1.1 Schedule and/or Duration............ 4.1

4.1.2 Direct Employment Schedule . . . . . . . . . . 4.2

4.1.3 Construction Land-Use Impacts . . . . . . . . . 4.2

4.2 OPERATION . . . . . . . . . . . . . . . . . . . . 4.2

4.2.1 Main Facility Direct Employment . . . . . . . . 4.3

4.2.2 Coal Mine Direct Employment . . . . . . . . . 4.3

4.2.3 Operation Land-Use Impacts .............. 4.3 
5.0 COAL GASIFICATION . . . . . . . . . . . 5.1

5.1 CONSTRUCTION .......................... 5.1

5.1 .1 Schedule and/or Duration .......... 5.1

5.1 .2 Direct Employment Schedule . . . . . . . . 5.2

5.1 .3 Construction Land-Use Impacts ......... 5.2

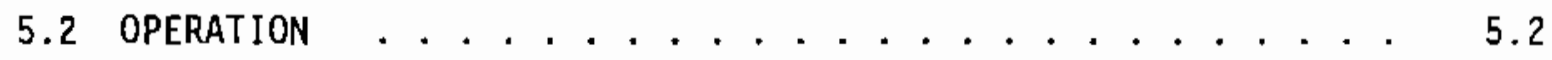

5.2.1 Main Facility Direct Employment . . . . . . . 5.2

5.2.2 Coal Mine Direct Employment . . . . . . . . . 5.3

5.2 .3 Operations Land-Use Impacts .......... 5.3

6.0 COGENERATION . . . . . . . . . . . . . . . . . . 6.1

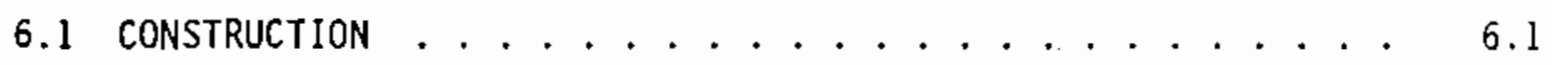

6.1 .1 Schedule and/or Duration ........... 6.1

6.1.2 Direct Employment Schedule . . . . . . . . . . 6.2

6.1 .3 Construction Land-Use Impacts .......... 6.3

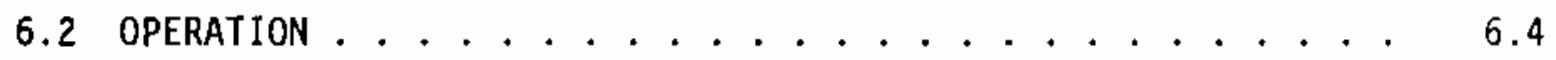

6.2 .1 Direct Employment . . . . . . . . . . . 6.4

6.2 .2 0peration Land-Use Impacts . . . . . . . . 6.4

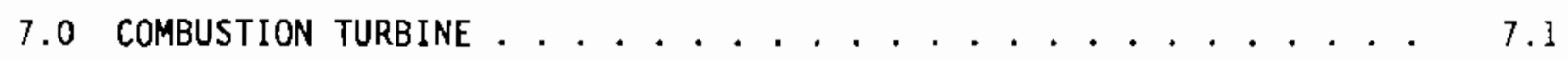

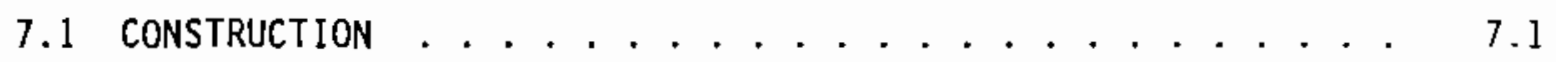

7.1 .1 Schedule and/or Duration . . . . . . . . . 7.1

7.1 .2 Direct Employment Schedule . . . . . . . . 7.3

7.1 .3 Construction Land-Use Impacts ......... 7.3

7.2 OPERATION . . . . . . . . . . . . . . . . 7.3

7.2 .1 Direct Employment ............ 7.3

7.2 .2 0peration Land-Use Impacts . . . . . . . 7.4 
8.0 GEOTHERMAL . . . . . . . . . . . . . . 8.1

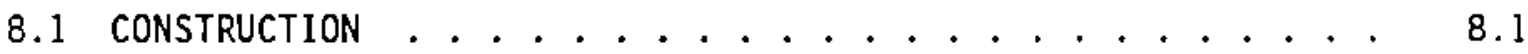

8.1.1 Schedule and/or Duration .......... 8.1

8.1.2 Direct Employment Schedule . . . . . . . . 8.1

8.1 .3 Construction Land-Use Impacts ........ 8.3

8.2 OPERATION . . . . . . . . . . . . . . . 8.4

8.2.1 Direct Employment . . . . . . . . . 8.4

8.2 .2 Operation Land-Use Impacts ......... 8.5

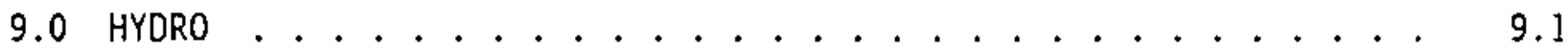

9.1 CONSTRUCTION . . . . . . . . . . . . . . . . 9.2

9.1.1 Schedule and/or Duration ............ 9.2

9.1.2 Direct Employment Schedule............ 9.2

9.1.3 Construction Land-Use Impacts .......... 9.3

9.2 OPERATION . . . . . . . . . . . . . . . . . . 9.4

9.2.1 Direct Employment . . . . . . . . . 9.4

9.2.2 Operation Land-Use Impacts . . . . . . . . 9.5

10.0 SOLAR . . . . . . . . . . . . . . . 10.1

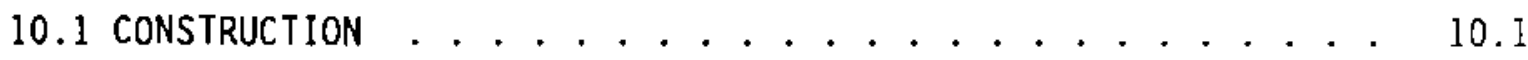

10.1.1 Schedule and/or Duration ......... 10.1

10.1.2 Direct Employment Schedule . . . . . . . 10.2

10.1.3 Construction Land-Use Impacts ......... 10.3

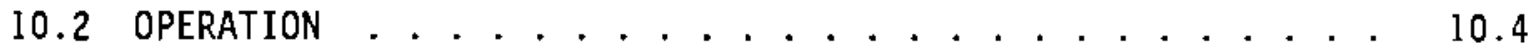

10.2.1 Direct Employment . . . . . . . . . . . 10.4

10.2.2 Operation Land-Use Impacts . . . . . . . . . 10.4

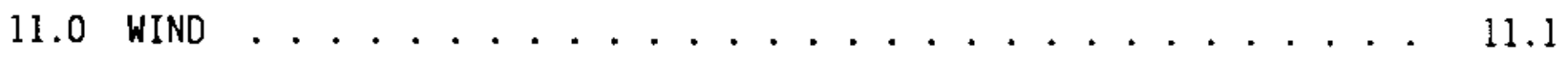

11.1 CONSTRUCTION . . . . . . . . . . . . . 11.1 
11.1.1 Schedule and/or Duration ........... 11.1

11.1 .2 Direct Employment Schedule .......... 11.1

11.1 .3 Construction Land-Use Impacts ......... 11.2

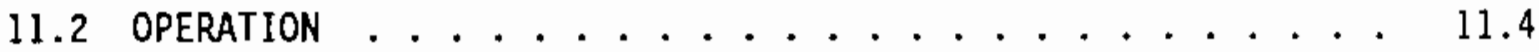

11.2.1 Direct Employment . . . . . . . . . . 11.4

11.2.2 Operation Land-Use Impacts . . . . . . . 11.4

12.0 NUCLEAR . . . . . . . . . . . . . . . . . . 12.1

12.1 CONSTRUCTION . . . . . . . . . . . 12.1

12.1.1 Schedule and/or Duration .......... 12.1

12.1.2 Direct Employment Schedule . . . . . . . 12.2

12.1.3 Construction Land-Use Impacts ........ 12.2

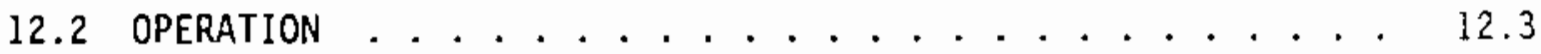

12.2.1 Direct Employment ............ 12.3

12.2.2 Operation Land-Use Impacts . . . . . . . 12.4

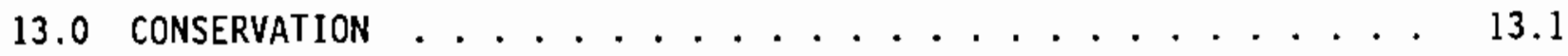

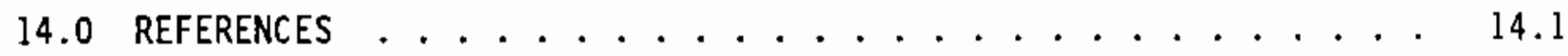

APPENDIX - DEVELOPMENT OF ASSUMPTIONS ............. A.I 


\section{TABLES}

3.1 Resource Summary for Pulverized Coal Plants . . . . . . . . . . 3.1

3.2 Coal Plant Construction Duration . . . . . . . . . . 3.2

3.3 Coal Plant Construction Duration by Capacity . . . . . . . . 3.3

3.4 Construction Manhours for Three Different Plant Sizes . . . . . . . 3.3

3.5 Average Annual Employment During Construction of 550-MW Coal PTant at Boardman . . . . . . . . . . . . . . . . . . 3.4

3.6 Employment Data for Construction of Nine Coal Plants . . . . . . 3.5

3.7 Work-Force Mix During Construction of Coal Creek Station Coal Plant 3.6

3.8 Work-force Mix for Each Quarter of Construction . . . . . . . 3.7

3.9 Construction Work-Force at North Dakota Coal Plant . . . . . . 3.8

3.10 Construction Work-Force at Wyoming Coal Plant . . . . . . . . . 3.8

3.11 Ratio of Local Service Jobs Created for Each Coal Plant Construction Job ...................... . . . . . . . . . . . . . . . . . . . . . .

3.12 Ratio of Direct to Indirect Employment at Boardman Plant . . . . 3.10

3.13 Acreage Requirements for Pulverized Coal Plants Showing Area Required for Disposal . . . . . . . . . . . . . . 3.11

3.14 Acreage Requirements for Pulverized Coal Plants . . . . . . . . 3.11

3.15 Number of Employees per Megawatt of Plant Capacity by Labor Category ....................... 3.13

3.16 O\&M Costs for Coal Plant Operation . . . . . . . . . . . . 3.13

3.17 Multipliers for Indirect Jobs Associated with Plant Operations Employment ..................... 3.15

3.18 Relationship between Power Generation and Land Use . . . . . . . 3.15

4.1 Resource Summary for Atmospheric Fluidized Bed Coal Plants . . . . . 4.1

4.2 Construction Cash flow ....................... 4.1

4.3 Employee Mix for AfBC Plant . . . . . . . . . . . . . . . . 4.3

5.1 Resource Summary for Coal Gasification Plants . . . . . . . . . 5.l 


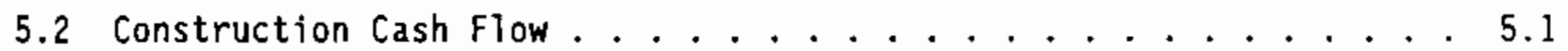

5.3 Operations Employment Mix cost and Levels at a IGCC Plant . . . . 5.3

6.1 Resource Summary for Cogeneration Plants . . . . . . . . . 6.1

6.2 Construction Duration for Cogeneration Plants . . . . . . 6.2

6.3 Employment Levels and Costs During Construction of a Cogeneration Plant ................... 6.3

6.4 Acreage Requirements for Siting a Cogeneration P1ant . . . . . . 6.4

7.1 Resource summary for Combustion Turbine Plants . . . . . . . . 7.1

7.2 Construction Duration for Combustion Turbine Plants . . . . . 7.2

7.3 Construction Schedule for a Combined-Cycle Combustion Turbine Plant 7.2

7.4 Acreage Requirements for Siting a Combined-Cycle Combustion Turbine Plant .................... 7.3

7.5 Employment Levels for Operation of a Combined-Cycle Combustion Turbine Plant ................ . . 7.4

7.6 Fixed Costs for Operation of Combined Cycle Combustion Turbine

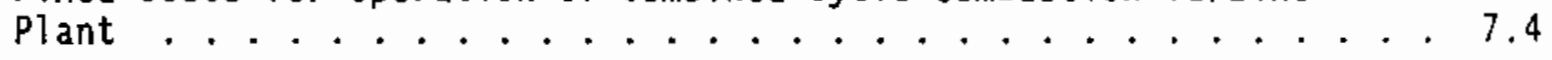

8.1 Resource Summary for Geothermal Systems . . . . . . . . . 8.1

8.2 Construction Duration for Geothermal Systems . . . . . . . . 8.2

8.3 Acreage Requirements for Geothermal Plants . . . . . . . . . . 8.4

8.4 Employment Levels for Geothermal Plants . . . . . . . . . . 8.4

9.1 Resource Summary for Hydro Electric Facilities . . . . . . . . . 9.1

9.2 Construction Duration for Hydro Electric Facilities . . . . . 9.2

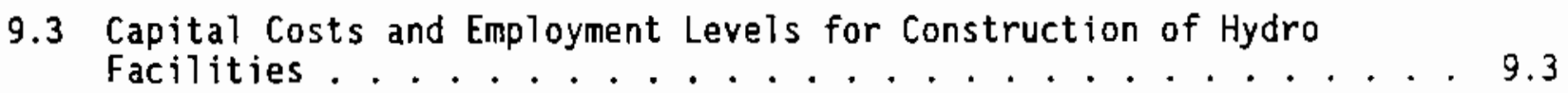

9.4 Labor Requirements for Hydro Facility Operation . . . . . . . . 9.5

10.1 Resource Summary for Solar Energy Plants . . . . . . . . . . 10.1

10.2 Labor Costs for Construction of Solar Generation Systems . . . . 10.2

10.3 Acreage Requirements for Solar Plants . . . . . . . . 10.3

11.1 Resource Summary for Wind Energy Generators . . . . . . . . . 11.1 
11.2 Construction Duration for Wind Energy Plants . . . . . . . 11.2

11.3 Construction Work-Force Requirements for Wind Energy Generators . I1.2

11.4 Acreage Requirements for Generator Types . . . . . . . . . 11.4

11.5 Operations Work-Force Requirements for Wind Energy Plants . . . 11.5

12.1 Resource Summary for Nuclear Plants . . . . . . . . . . 12.1

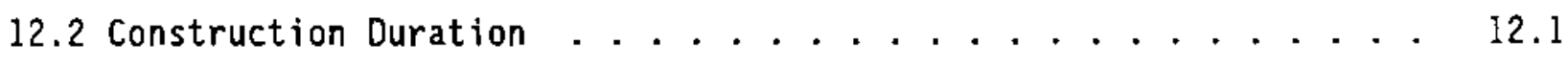

12.3 Employment Levels During Construction of Nuclear Plants . . . . 12.2

12.4 Acreage Requirements for a 1,250-MW Nuclear plant . . . . . . . 12.3

12.5 Employment Levels Required During Operation of a Nuclear Plant . . 12.4

13.1 Employment Levels for Construction of Various Conservation

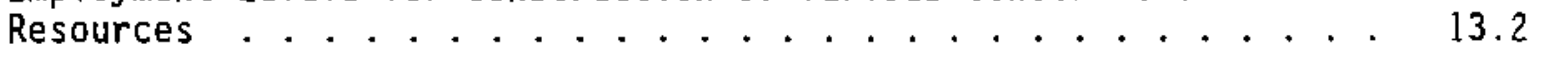


. 


\subsection{INTROOUCTION}

This report describes work conducted by the Pacific Northwest Laboratory (PNL) to assist the Bonneville Power Administration (Bonneville) in evaluating the impacts of new power resources. This report focuses on impacts to employment and land use that would result from the implementation of different energy resource alternatives that Bonneville is considering using to meet growing electric energy needs in the Pacific Northwest. These alternatives are described in Bonneville's Resource Program Environmental Impact Statement (RPEIS) (BPA 1991).

This report is organized as follows. Chapter 2 describes the spreadsheet analyses methodology used to assess each of the resource alternatives. Chapter 3 through 12 describe the calculations and assumptions used to estimate impacts for each energy resource. Each resource description begins with a summary table of the impacts for that resource. The remainder of the resource description is broken down by construction and operation. Within these divisions data are presented on direct employment and on land use impacts. In addition, the construction discussions are preceded with data on the duration and scheduling of construction, a critical factor in evaluating impacts. Information on the breakdown of the labor impacts by skill mix is presented for pulverized coal (construction only), combustion turbines (operations only), and geothermal (operations only). Employment multipliers are presented for pulverized coal. No multipliers were located for the other resources, and hence all employment impacts are direct employment impacts.

Chapter 13 is references. The appendix show the development of the assumptions on which the analyses were based. 
- 


\subsection{ANALYSIS METHODOLOGY}

The following analyses were used to estimate impacts for each of the alternatives. For operation employment impacts for cogeneration, we used the factor from natural gas-fired combined-cycle combustion turbines. We found no estimate of employment needs for natural gas-fired cogeneration, which is the fuel Bonneville assumes that all cogeneration will employ for purposes of the EIS analysis.

Estimates of operations employment were a simple matter of multiplying the factor for each resource by the average megawatts of generation (or load reduction) expected for each energy resource type in each alternative. In this approach we assume that the annual generation rate in average megawatts accounts for the quantity of time that operation employees would be affected by Bonneville actions. Conservation resources (rather than the Emphasize Conservation Alternative) do not result in operations employment in our analysis.

Construction employment is a one-time event. Once a particular plant is constructed, or a conservation measure is installed, construction employment ends. Therefore, estimates of construction employment required that we address only new plants constructed in any given time period. To estimate new construction, we calculated the differences in generation between each year from 1991 to 2010. We assume that increased generation, over and above that reported in any previous year, results from new construction. Even though we do not accurately determine when a new plant is built, this approach does capture the employment resulting from construction as new electricity generation capacity is put in place to generate average megawatts. This approach addresses the energy requirements of Bonneville.

For consistency with the analysis of other types of impacts, we sum the effects to show impacts for the three study years of 1991, 2000, and 2010. Impacts that appear to occur in 1991 represent all plant construction up to that time. Employment from conservation activities occurring prior to 1991 is not estimated. Impacts that are shown for the year 2000 include those occurring from both new plant construction and conservation from 1992 through 
2000. Impacts that are shown for 2010 include those occurring from both new plant construction and conservation from 2001 through 2010. 


\subsection{PULVERIZED COAL}

A summary of the impacts of the construction and operation of pulverized coal plants on employment and land use is shown in Table 3.1. Sections 3.1 and 3.2 provide detailed discussions of how these impacts were determined.

TABLE 3.1. Resource Summary for Pulverized Coal Plants

\begin{tabular}{|c|c|c|}
\hline & Employment ${ }^{(a)}$ & Land Use ${ }^{(b)}$ \\
\hline Construction & 4.7 & 1.0 \\
\hline Operation & 0.5 & 0.2 \\
\hline
\end{tabular}

(a) Construction is in employee years per megawatt capacity; operation is in employees per year per megawatt capacity.

(b) Construction is in total acres disturbed per megawatt capacity; operation is in acres disturbed per year per megawatt capacity.

\subsection{CONSTRUCTION}

This section discusses the scheduling and duration of 19 different coal plant construction projects; the direct employment requirements of $14 \mathrm{coal}$ plant construction projects; the skill mix of the construction workers at three coal plant construction projects; the employment multipliers estimated by four different studies; and the construction land impacts of seven different coal piants.

\subsubsection{Schedule and/or Duration}

The scheduling and duration of a major construction project is an important factor in determining the level of impact from the project, especially in rural, sparsely populated areas. The data used came from a number of sources dealing with the duration of construction for coal plants. On average, for the 19 coal plants for which construction duration data was collected, the project took 79.58 months to complete, or 0.12 months per megawatt. The plant capacity ranged in size from $270 \mathrm{MW}$ to $1,500 \mathrm{MW}$. The collected data is summarized in Table 3.2. 
IABLE 3.2. Coal Plant Construction Duration

\begin{tabular}{|c|c|c|c|}
\hline $\begin{array}{l}\text { Capacity } \\
\text { (MW) }\end{array}$ & $\begin{array}{l}\text { Duration } \\
\text { (months) }\end{array}$ & $\begin{array}{l}\text { Months } \\
\text { per MW }\end{array}$ & Source \\
\hline 1,000 & 72 & 0.07 & DRI 1982 \\
\hline 504 & 60 & 0.12 & DRI 1982 \\
\hline 550 & 60 & 0.11 & DRI 1982 \\
\hline 1,500 & 84 & 0.06 & DRI 1982 \\
\hline 1,180 & 120 & 0.10 & DRI 1982 \\
\hline 1,200 & 72 & 0.06 & DRI 1982 \\
\hline 600 & 72 & 0.12 & DRI 1982 \\
\hline 700 & 72 & 0.10 & DRI 1982 \\
\hline 700 & 108 & 0.15 & DRI 1982 \\
\hline 500 & 84 & 0.17 & OTA 1985 \\
\hline 270 & 72 & 0.27 & BPA 1985 \\
\hline 540 & 84 & 0.16 & BPA 1985 \\
\hline 1,300 & 84 & 0.06 & BPA 1985 \\
\hline 1,300 & 96 & 0.07 & BPA 1987 \\
\hline 540 & 72 & 0.13 & BPA 1987 \\
\hline 270 & 60 & 0.22 & BPA 1987 \\
\hline 550 & 84 & 0.15 & ECO Northwest 1983 \\
\hline 500 & 72 & 0.14 & NWPPC 1989a \\
\hline 1,206 & 84 & 0.07 & NWPPC $1989 a$ \\
\hline 785 & 80 & 0.12 & Average \\
\hline
\end{tabular}

A more refined estimate of construction duration is obtained by classifying the plants into three capacity categories: less than $500 \mathrm{MW} ; 500$ to $999 \mathrm{MW}$; and 1,000 $\mathrm{MW}$ or over. Table 3.3 shows the average duration of construction, in both months and months per megawatt, for the three size categories. 
TABLE 3.3. Coal Plant Construction Duration by Capacity

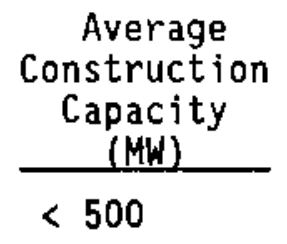

500 to 999

$1,000+$
Average

Construction

Duration

(months)

66.0

76.8

87.4
Duration

(months/MW)

0.24

0.14

0.07

\subsubsection{Direct Employment Schedule}

A number of sources cite employment impacts for conventional coal. At the most disaggregated level, the estimate derived in a recent Worldwatch Institute report (Flavin and Lenssen 1990) is significant. This study estimates the direct employment impact of coal-fired electricity generation to be 116 jobs per thousand gigawatt-hours annually, which includes the impact of coal mining, plant construction, and facility operation.

Fourteen estimates of construction employee years per MW capacity are developed below. The average of all the estimates is 4.7 ; the range is 1.6 to 8.3 years per MW.

Bonnevilie's Comparative Electric Generation Study (BPA 1987) presents estimates of construction manhours for three different size plants. This allows calculation of the employee years per MW, assuming a 2,000 hour employee year, as shown in Table 3.4. On average, the three plants required 4.5 construction employee years per MW capacity, although this appears to be inversely related to the size of the plant.

TABLE 3.4. Construction Manhours for Three Different Plant Sizes

\begin{tabular}{|c|c|c|c|c|}
\hline $\begin{array}{l}\text { Total } \\
\text { Capacity } \\
(M N) \\
\end{array}$ & Configuration & $\begin{array}{c}\text { Construction } \\
\text { Manhours } \\
\end{array}$ & $\begin{array}{l}\text { Manhours } \\
\text { per MW }\end{array}$ & $\begin{array}{l}\text { Employee } \\
\text { Years } \\
\text { per MH }\end{array}$ \\
\hline 1,300 & two $650-\mathrm{MW}$ units & $9,740,212$ & 7,492 & 3.7 \\
\hline 540 & two $270-\mathrm{MW}$ units & $5,106,333$ & 9,546 & 4.7 \\
\hline 270 & one $270-\mathrm{MW}$ unit & $2,762,622$ & 10,232 & 5.1 \\
\hline
\end{tabular}


An ECO Northwest report (ECO Northwest 1983) for Bonnevilie on the effects of the 550-MW coal-fired generating plant at Boardman, Oregon, estimates peak construction employment at 1,566, and breaks the average annual construction employment down as shown in Table 3.5 .

TABLE 3.5. Average Annual Employment During Construction of 550-MW Coal Plant at Boardman

$\begin{array}{cc}\text { Year } & \text { Avg. Annual Direct Employment } \\ 1975 & 20 \\ 1976 & 240 \\ 1977 & 370 \\ 1978 & 680 \\ 1979 & 1,043 \\ 1980 & 1,045 \\ 1981 & 430 \\ 1982 & 160\end{array}$

Summing the employment figures results in a total construction employeeyears of 3,988, or approximately 7.3 employee-years per megawatt of capacity.

An EPRI report prepared by the Denver Research Institute (DRI 1982) analyzed nine coal-fired plants. The institute found that, while the bulk of the socioeconomic effects of the plants were a result of the influx of construction workers, the level of peak construction was rarely predicted successfully ahead of time. Table 3.6 gives the capacity, construction manhours, employee years per MW capacity, and peak labor force per MW capacity for each of the coal-fired plants analyzed in the study. The average plant had a capacity of $898 \mathrm{MW}$ and required 4.4 employee years per $M W$ to build. At peak construction employment levels, the average plant employed 2.2 workers per megawatt capacity. 
TABLE 3.6. Employment Data for Construction of Nine Coal Plants

\begin{tabular}{|c|c|c|c|c|}
\hline Plant & $\begin{array}{c}\text { Capacity } \\
\text { (MW) }\end{array}$ & $\begin{array}{l}\text { Manhours } \\
\text { (Total) }\end{array}$ & $\begin{array}{l}\text { Employee } \\
\text { Years } \\
\text { (per MW) }\end{array}$ & $\begin{array}{c}\text { Peak } \\
\text { Employment } \\
\text { (Emp loyees } \\
\text { per MW) }\end{array}$ \\
\hline Coal Creek, ND & 1,000 & $8,297,000$ & 4.1 & 2.1 \\
\hline Clay Boswe11, MN & 500 & $4,165,968$ & 4.2 & 3.1 \\
\hline Boardman, OR & 550 & $4,606,760$ & 4.2 & 2.7 \\
\hline Laramie River, WY & 1,500 & $11,064,000$ & 3.7 & 2.4 \\
\hline Newton, IL & 1,180 & $8,348,500$ & 3.5 & 1.2 \\
\hline Fayette, TX & 1,200 & $3,793,000$ & 1.6 & 0.7 \\
\hline Homer City \#3, PA & 600 & $4,809,500$ & 4.0 & 2.1 \\
\hline Coronado \#1 \& \#2, AZ & 700 & $11,550,000$ & 8.3 & 3.7 \\
\hline Cholla \#2, \#3, \&\#4, AZ & 850 & $10,689,600$ & 6.3 & 1.7 \\
\hline Average & 898 & $7,480,481$ & 4.4 & 2.2 \\
\hline
\end{tabular}

Finally, the Office of Applied Energy Studies at Washington State University is cited in a Charles River Associates report (Charles River Associates 1984) as estimating that construction of coal plants directly generates 5 employee years per million 1983 dollars invested, or 4.1 years per one million 1989 dollars. Estimates of capital costs from a number of sources indicate that the average capital cost for construction of a pulverized coal plant is approximately $\$ 1.242$ million in 1989 dollars per MW capacity. Therefore, the Charles River estimate implies that construction of pulverized coal plants results in 5.1 employee years per $M W$ of capacity in direct employment impacts.

\subsubsection{Skill Mix of Construction Employees}

Data on the skill mix of the coal plant construction work force was also located in the Charles River Associates report (1984). The document provides data on the skill mix of the construction employees and its change over time. Table 3.7 gives the average skill mix of the construction work force at the Coal Creek Station coal plant (located in North Dakota), during the 1975 to 1979 period. 
TABLE 3.7. Work Force Mix During Construction of Coal Creek Station Coal Plant

\begin{tabular}{lc}
\multicolumn{1}{c}{ Craft } & $\begin{array}{c}\text { Percent of Total Work Force } \\
\text { (Quarterly Average) }\end{array}$ \\
Ironworker & $14 \%$ \\
Electrician & $13 \%$ \\
Pipefitter & $12 \%$ \\
Operator & $12 \%$ \\
Laborer & $11 \%$ \\
Boilermaker & $9 \%$ \\
Supervision & $9 \%$ \\
Carpenter & $8 \%$ \\
Sheetmetal & $4 \%$ \\
Mitlwright & $1 \%$ \\
Cement Finisher & $1 \%$ \\
Insulator & $1 \%$ \\
Teamster & $1 \%$ \\
Bricklayer & $1 \%$ \\
Painter & $1 \%$ \\
Total & $100 \%$
\end{tabular}

Table 3.8 gives the skill mix for each quarter during construction of the Coal Creek Station Coal Plant, a period lasting from the third quarter of 1975 to the second quarter of 1979.

A 1979 study (Murdock and Leistritz 1979) categorized skills at two coal plants, one in North Dakota in 1975 and one in Wyoming in 1976. These ski11 mixes are presented in Tables 3.9 and 3.10. Included in the data are the average worker wage, the average worker age, and the length of time employed at this and previous jobs. 
IABLE 3.8. Work Force Mix for Each Quarter of Construction

Percent of Total Work Force

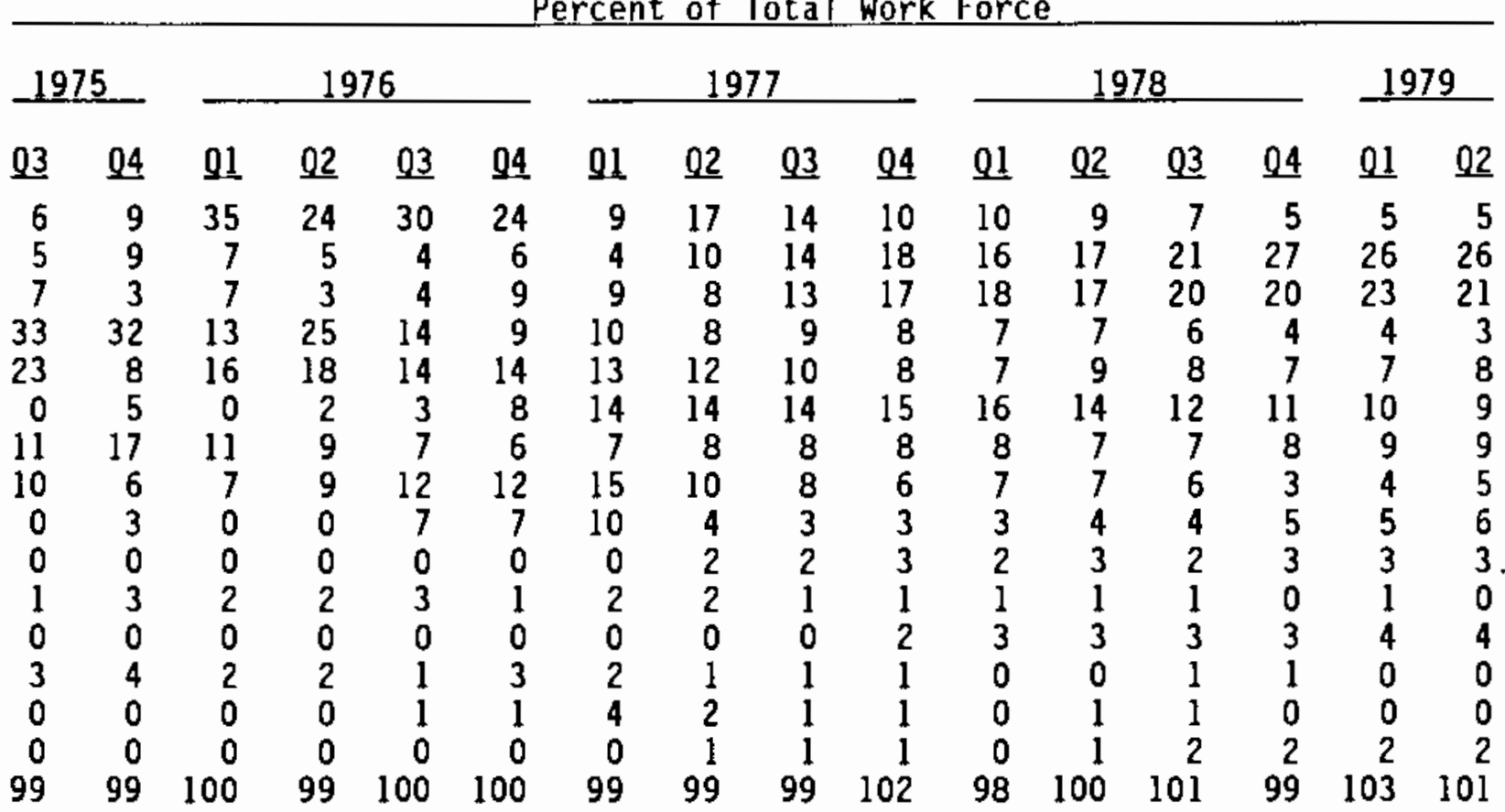


IABLE 3.9. Construction Work Force at North Dakota Coal Plant

\begin{tabular}{|c|c|c|c|c|c|}
\hline Job Classification & $\begin{array}{l}\text { Percent } \\
\text { of Work } \\
\text { Force } \\
\end{array}$ & $\begin{array}{l}\text { Average } \\
\text { Hourly } \\
\text { Wage (1975 } \\
\text { dollars) } \\
\end{array}$ & $\begin{array}{l}\text { Average } \\
\text { Age } \\
\text { (years) }\end{array}$ & $\begin{array}{l}\text { Length } \\
\text { Employed } \\
\text { Present } \\
\text { Job } \\
\text { (years) }\end{array}$ & $\begin{array}{c}\text { Length } \\
\text { Employed } \\
\text { Previous } \\
\text { Job } \\
\text { (years) }\end{array}$ \\
\hline $\begin{array}{l}\text { Supervisory } \\
\text { Professional-technical } \\
\text { Craftsmen: } \\
\text { Electrician } \\
\text { Mechanics \& welders } \\
\text { Pipe fitter } \\
\text { Power Plant Operator }\end{array}$ & $\begin{array}{r}6.8 \\
8.0 \\
61.8 \\
11.4 \\
3.8 \\
35.6\end{array}$ & $\begin{array}{l}7.97 \\
8.58 \\
8.25 \\
9.12 \\
8.14 \\
8.04\end{array}$ & $\begin{array}{l}46.0 \\
33.4 \\
36.4 \\
38.2 \\
36.8 \\
35.1\end{array}$ & $\begin{array}{l}8.7 \\
2.2 \\
1.2 \\
0.5 \\
2.8 \\
0.9 \\
--.\end{array}$ & $\begin{array}{l}2.3 \\
2.3 \\
2.0 \\
1.8 \\
2.1 \\
1.9 \\
\cdots\end{array}$ \\
\hline $\begin{array}{l}\text { Power Plant Operator } \\
\text { Technician }\end{array}$ & -- & -- & -- & -- & $\begin{array}{l}\cdots \\
--\end{array}$ \\
\hline $\begin{array}{l}\text { Other } \\
\text { Laborer } \\
\text { Operatives: }\end{array}$ & $\begin{array}{r}11.0 \\
15.2 \\
4.9\end{array}$ & $\begin{array}{l}8.04 \\
5.14 \\
7.05\end{array}$ & $\begin{array}{l}38.4 \\
32.1 \\
44.2\end{array}$ & $\begin{array}{l}2.1 \\
1.7 \\
6.5\end{array}$ & $\begin{array}{l}2.6 \\
1.9 \\
2.1\end{array}$ \\
\hline $\begin{array}{l}\text { Heavy equipment } \\
\text { Other }\end{array}$ & $\begin{array}{l}-- \\
-\end{array}$ & $\begin{array}{l}-- \\
-\end{array}$ & $\begin{array}{l}-- \\
-\end{array}$ & -- & -- \\
\hline Clerical \& Other & 3.4 & 3.78 & 25.4 & 1.5 & 1.7 \\
\hline $\begin{array}{r}\text { Total } \\
N=\end{array}$ & $\begin{array}{l}100.0 \\
264\end{array}$ & 7.39 & 36.3 & 2.1 & 2.0 \\
\hline
\end{tabular}

IABLE 3,10. Construction Work Force at Wyoming Coal Plant

\begin{tabular}{|c|c|c|c|c|}
\hline Job Classification & $\begin{array}{l}\text { Percent } \\
\text { of Work } \\
\text { Force } \\
\end{array}$ & $\begin{array}{l}\text { Average } \\
\text { Hourly } \\
\text { Wage (1976 } \\
\text { dollars) } \\
\end{array}$ & $\begin{array}{c}\text { Average } \\
\text { Age } \\
\text { (years) }\end{array}$ & $\begin{array}{l}\text { Length } \\
\text { Employed } \\
\text { Present } \\
\text { Job } \\
\text { (vears) }\end{array}$ \\
\hline $\begin{array}{l}\text { Supervisory } \\
\text { Professional-technical } \\
\text { Craftsmen: } \\
\text { Electrician } \\
\text { Mechanics \& welders }\end{array}$ & $\begin{array}{r}6.3 \\
3.5 \\
45.7 \\
4.8 \\
17.9\end{array}$ & $\begin{array}{r}12.14 \\
8.04 \\
8.21 \\
8.18 \\
8.42\end{array}$ & $\begin{array}{l}37.8 \\
33.4 \\
34.3 \\
34.9 \\
34.1\end{array}$ & $\begin{array}{l}7.7 \\
6.0 \\
3.8 \\
3.9 \\
3.7\end{array}$ \\
\hline $\begin{array}{l}\text { Pipe fitter } \\
\text { Power Plant operator } \\
\text { Technician } \\
\text { Other } \\
\text { Laborer }\end{array}$ & $\begin{array}{r}r .- \\
13.4 \\
5.1 \\
4.5 \\
11.4\end{array}$ & $\begin{array}{l}8.16 \\
8.09 \\
7.68 \\
5.11\end{array}$ & $\begin{array}{l}33.0 \\
35.0 \\
37.3 \\
27.3\end{array}$ & $\begin{array}{l}-- \\
4.3 \\
3.4 \\
3.5 \\
1.2\end{array}$ \\
\hline $\begin{array}{l}\text { Operatives: } \\
\text { Heavy equipment } \\
\text { Other } \\
\text { Clerical \& 0ther }\end{array}$ & $\begin{array}{r}25.3 \\
3.3 \\
4.5\end{array}$ & $\begin{array}{l}7.52 \\
6.23 \\
6.00\end{array}$ & $\begin{array}{l}34.3 \\
26.2 \\
33.8\end{array}$ & $\begin{array}{l}2.7 \\
0.7 \\
3.1\end{array}$ \\
\hline $\begin{array}{r}\text { Total } \\
\mathbf{N}=\end{array}$ & $\begin{array}{l}100.0 \\
396\end{array}$ & 7.60 & 33.4 & 3.7 \\
\hline
\end{tabular}




\subsubsection{Employment Multiplier(s)}

Employment multipliers refer to the employment created when direct employees (construction workers, supervisors) spend their incomes. The employment multiplier is the number of indirect jobs created for each direct job. A similar concept is the income multiplier, which is the number of dollars generated for each dollar paid to direct employees. Both are presented in this section.

A Charles River Associates study (1984) cites 31 induced employee years per one million 1983 dollars invested in coal construction. Using the gross national product (GNP) price deflator, these figures convert to 25 induced employee years per one million 1989 dollars.

In contrast, a Denver Research Institute study (1982) finds that the local service-to-construction worker ratio rarely exceeded 0.2 in the 12 case studies analyzed, nine of which were coal plants. This report states "In general, local service-to-basic ratios are lower in less well developed areas where a higher proportion of purchases are made outside the impact area.... Multipliers are lowest in Boardman, Laramie River, and Coronado... These ... areas are the most sparsely populated."

In the same study, the Denver Research Institute (1982) finds the local service-to-basic construction employment ratios given in Table 3.11 to be generally applicable.

IABLE 3.11. Ratio of Local Service Jobs Created for Each Coal Plant Construction Job

Type of Impact Area

Rural, sparsely populated, no large trade center within impact area

More urbanized, moderate population densities

Fringe of metropolitan area

\begin{tabular}{cc} 
In-Migrating Construction Workers \\
$\begin{array}{cc}\text { Ratio to } & \text { Ratio to } \\
\text { Peak } & \text { Annual Average }\end{array}$ \\
\hline
\end{tabular}

$0.1-0.2$

$0.2-0.3$

$0.1-0.2$

$0.3-0.4$

$0.2-0.3$

$0.4-0.5$ 
Table 3.12 shows the ratio of direct to indirect employment found in the ECO Northwest survey (1983) of the coal plant at Boardman.

IABLE 3.12. Ratio of Direct to Indirect Employment at Boardman Plant

$\begin{array}{cccc}\frac{\text { Year }}{1975} & \begin{array}{c}\text { Direct } \\ \text { Employment }\end{array} & \begin{array}{c}\text { Indirect } \\ \text { Employment }\end{array} & \begin{array}{c}\text { Implied } \\ \text { Multiplier }\end{array} \\ 1976 & 20 & 4 & 0.20 \\ 1977 & 240 & 48 & 0.20 \\ 1978 & 370 & 74 & 0.20 \\ 1979 & 680 & 136 & 0.20 \\ 1980 & 1,043 & 219 & 0.21 \\ 1981 & 1,045 & 209 & 0.20 \\ 1982 & 430 & 86 & 0.20 \\ & 160 & 240 & 1.50\end{array}$

Operation at this plant began in 1980 , so the multipliers for 1980,1981 , and 1982 are for both operating and construction personnel.

\subsubsection{Construction Land-Use Impacts}

Construction land-use impacts consist of the area that must be cleared for the plant. Information on the actual land area required by a plant is scarce and the information that does exist is quite varied. A number of sources were used to derive the estimate of 1.04 acres per MW capacity. The development of this estimate is described below.

A PNL report for Bonneville (Baechler, Fickeisen, and Hendrickson 1990) reports that $\mathrm{plants}$ typically occupy 40 acres for a 350-MW plant, and 700 acres for a 2,100-MW plant. This works out to 0.11 and 0.33 acres per MW, respectively. The same source indicates that the 550-MW plant at 80 ardman occupies 3,525 acres, or 6.41 acres per MW. Baechler indicates that the Boardman plant occupies an unusually large area. Baechler also states that several thousand additional acres are required for ash and sludge disposal.

The Office of Technology Assessment (OTA 1985) reports a pulverized coal plant of $714 \mathrm{MW}$ as occupying 640 acres, or 0.90 acres per MW. 
Bonneville's Comparative Electric Generation Study (BPA 1987) gives land use information for three putverized coal plants, as shown in Table 3.13.

IABLE 3.13. Acreage Requirements for Pulverized Coal Plants Showing Area Required for Disposal

\begin{tabular}{|c|c|c|c|}
\hline $\begin{array}{l}\text { Capacity } \\
\text { (MW) }\end{array}$ & $\begin{array}{l}\text { Site } \\
\text { Area } \\
\text { (acres) }\end{array}$ & $\begin{array}{c}\text { Disposal } \\
\text { Area } \\
\text { (acres) }\end{array}$ & $\begin{array}{l}\text { Total } \\
\text { Acres } \\
\text { per MW }\end{array}$ \\
\hline 1,300 & 400 & 1,130 & 1.18 \\
\hline 540 & 300 & 450 & 1.39 \\
\hline 270 & 380 & 250 & 2.33 \\
\hline
\end{tabular}

Table 3.14 incorporates these various sources of land-use data.

IABLE 3.14. Acreage Requirements for Pulverized Coal Plants

\begin{tabular}{|c|c|c|c|}
\hline $\begin{array}{c}\text { Capacity } \\
(M W) \\
\end{array}$ & $\begin{array}{l}\text { Total Area } \\
\text { (acres) }\end{array}$ & $\begin{array}{l}\text { Acres } \\
\text { per MW }\end{array}$ & Source \\
\hline 270 & 630 & 2.33 & BPA 1987 \\
\hline 350 & 40 & 0.11 & Baechler, Fickeisen \& Hendrickson 1990 \\
\hline 540 & 750 & 1.39 & BPA 1987 \\
\hline 550 & 3,525 & 6.41 & Baechler, Fickeisen \& Hendrickson 1990 \\
\hline 714 & 640 & 0.90 & OTA 1985 \\
\hline 1,300 & 1,530 & 1.18 & BPA 1987 \\
\hline 2,100 & 700 & 0.33 & Baechler, Fickeisen \& Hendrickson 1990 \\
\hline
\end{tabular}

With the exception of the Boardman plant, the acres per MW figure varies between 0.11 and 2.33 , with a mean of 1.04 .

\subsection{OPERATION}

Operations impacts for all types of coal generation include both the impacts directly attributable to the generating $p l a n t$ and the impacts attributable to the mining operation that supplies the coal. This section begins with a discussion of the employment impacts of the generating $p l a n t$, and is followed by a discussion of the impacts due to the coal mining operation. A brief discussion of employment multipliers is followed by a 
description of the land-use impacts attributable to operation of the generating plant. As the land-use impacts of the site itself have already been discussed in Section 3.1.5, this section deals with the land-use impacts attributable to the coal mining operation.

The total operations employment impact of 0.46 employees per year per MW capacity is obtained by summing the main facility estimate of 0.33 employees and the coal mining estimate of 0.13 employees. The derivation of these estimates is described in the next two sections.

\subsubsection{Main Facility Direct Employment}

Reports by Bonneville (BPA 1987) and the U.S. Department of Energy (DOE 1983) contain estimates of the number of operations and management (0\&M) workers per MW of capacity. On average, 0.33 08M employees per MW of capacity are employed each year. This estimate is consistent with the three estimates developed below, and was chosen to represent this resource.

The Bonneville report cited also provides skill breakdowns for three pulverized coal case studies as presented in Table 3.15. This table shows an inverse relationship between number of employees per MW capacity and capacity. The distribution of total 0\&M employees over the job classifications remains fairly stable; however, operators account for $39 \%$ to $40 \%$ of the O\&M work force in a11 three plants, while maintenance represents $32 \%$ to $36 \%$.

The estimate of 0.33 employees per MW capacity is consistent with an International Energy Agency report (1989) which estimates that a 1,144-MW coal plant consisting of two units will require 301 O\&M employees, or 0.3 per MW capacity. This report states that labor accounts for $29 \%$ of fixed 0\&M costs in coal plants.

Two studies by the Northwest Power Planning Council (NWPPC 1989a and NWPPC 1989d) and one by Bonneville (BPA 1985) provide estimates of the fixed 08M costs per MW of capacity associated with 10 pulverized coal plants, as presented in Table 3.16. Using the average annual labor costs for pulverized coal operators of $\$ 37,492$ (See the Appendix to this report), an average of 0.33 08M employees per MW was calculated. Non labor costs are extraneous to our analysis. All costs have been inflated to 1989 dollars using the GNP price deflator. 
IABLE 3.15. Number of Employees per Megawatt of Plant Capacity by Labor Category

\begin{tabular}{|c|c|c|c|c|c|c|c|c|c|}
\hline \multirow[b]{2}{*}{$\begin{array}{l}\text { O\&M Labor } \\
\text { Category }\end{array}$} & \multicolumn{3}{|c|}{ Case Study 1} & \multicolumn{3}{|c|}{ Case Study 2} & \multicolumn{3}{|c|}{ Case Study 3} \\
\hline & Total & $\begin{array}{c}\text { per } \\
\text { MW }\end{array}$ & $\%$ & Iotal & $\begin{array}{l}\text { per } \\
\text { MW } \\
\end{array}$ & $\%$ & Iotal & $\begin{array}{l}\text { per } \\
\mathrm{MH} \\
\end{array}$ & $\%$ \\
\hline Capacity (MW) & 1300 & & & 540 & & & 270 & & \\
\hline Operators & 100 & 0.08 & 40 & 80 & 0.15 & 40 & 60 & 0.22 & 39 \\
\hline Maintenance & 90 & 0.07 & 36 & 70 & 0.13 & 35 & 50 & 0.19 & 32 \\
\hline Gate Security & 12 & 0.01 & 5 & 10 & 0.02 & 5 & 10 & 0.04 & 6 \\
\hline Labs/Stores & 13 & 0.01 & 5 & 10 & 0.02 & 5 & 10 & 0.04 & 6 \\
\hline General Help & 25 & 0.02 & 10 & 20 & 0.04 & 10 & 15 & 0.06 & 10 \\
\hline Supervisors & 11 & 0.01 & 4 & 9 & 0.02 & 5 & 9 & 0.03 & 6 \\
\hline Total & 251 & 0.19 & & 199 & 0.37 & & 154 & 0.57 & \\
\hline
\end{tabular}

IABLE 3.16. O\&M Costs for Coal Piant Operation

\begin{tabular}{|c|c|c|c|c|}
\hline Source & $\begin{array}{l}\text { Capacity } \\
\text { (MW) }\end{array}$ & $\begin{array}{c}\text { Fixed } \\
0 \& M \text { Costs } \\
(\$ / \mathrm{kW} / \mathrm{yr})\end{array}$ & $\begin{array}{l}\text { Labor } \\
\text { O\&M Costs } \\
(\$ / M W / y r)\end{array}$ & $\begin{array}{c}\text { Total } \\
\text { Employees } \\
\text { per MW }\end{array}$ \\
\hline BPA 1985 & 270 & $\$ 29$ & $\$ 8,410$ & 0.22 \\
\hline BPA 1985 & 540 & $\$ 20$ & $\$ 5,800$ & 0.15 \\
\hline BPA 1985 & 1,300 & $\$ 10$ & $\$ 2,900$ & 0.08 \\
\hline NWPPC 1989a & 500 & $\$ 33$ & $\$ 9,570$ & 0.26 \\
\hline NWPPC 1989a & 1,206 & $\$ 21$ & $\$ 6,090$ & 0.16 \\
\hline NWPPC 1989d & 1,576 & $\$ 60$ & $\$ 17,400$ & 0.46 \\
\hline NWPPC 1989d & 1,206 & $\$ 31$ & $\$ 8,990$ & 0.24 \\
\hline NWPPC 1989d & 1,206 & $\$ 44$ & $\$ 12,760$ & 0.34 \\
\hline NWPPC 1989d & 1,000 & $\$ 57$ & $\$ 16,530$ & 0.44 \\
\hline NWPPC 1989d & 1,676 & $\$ 126$ & $\$ 36,540$ & 0.97 \\
\hline Average & 1,048 & $\$ 43$ & $\$ 12,470$ & 0.33 \\
\hline $\operatorname{Max}$ & 1,676 & $\$ 126$ & $\$ 36,540$ & 0.97 \\
\hline Min & 270 & $\$ 10$ & $\$ 2,900$ & 0.08 \\
\hline
\end{tabular}




\subsubsection{Coal Mine Direct Employment}

The Energy Technology Characterizations Handbook (DOE 1983) estimates that a western surface coal mine with a preparation plant requires 1.53 workers per quadrillion Btu produced, assuming a heat rate of 8,750 Btu per pound of coal. Given Bonneville's assumption of a heat rate of $10,856 \mathrm{Btu} / \mathrm{kWh}$ for a pulverized coal plant, we calculate mining employment impacts of 0.15 employees per MW of generation. Assuming a capacity factor of 0.8 results in an estimate of 0.12 mine employees per MW capacity per year. This plant capacity factor falls within the range of 0.75 to 0.80 that are frequently cited (DOE 1983, and $\mathrm{BPA}^{(0)}$ ).

\subsubsection{Employment Multiplier(s)}

Overall, the semi-permanence of 0\&M jobs would lead us to expect a larger multiplier with 0\&M jobs than is associated with construction jobs.

Some evidence of the multipliers associated with O\&M jobs can be gleaned from a report by ECO Northwest (1983) on economic impacts of the environmental effects of a coal-fired electric generator. While this source does not distinguish between construction and 0\&M jobs, it provides direct and indirect plant employment figures for the periods between 1975 and 1982 (the plant started operation in 1980). The multiplier is roughly constant at 0.20 from 1975 to 1981 , and then rises sharply to 1.50 in 1982 .

A Denver Research Institute study (1982) finds the multiplier associated with in-migrating operating employees to be between 0.3 and 0.8 , depending on the type of impact area (see Table 3.17).

A reasonable estimate would appear to be 0.5 jobs created for every direct operations job.

\subsubsection{Operation Land-Use Impacts}

Operations land-use impacts consist of the land disturbed for coal mining and transportation. The land used to site the plant is discussed in Section 3.1.5.

(4) Bonneville Power Administration. 1990. Draft 1990 Generating Resources Supply Forecast. Bonneville Power Administration, Portland, Oregon. 
TABLE 3.17. Multipliers for Indirect Jobs Associated with Plant Operations Employment

\begin{tabular}{lc} 
Type of Impact Area & $\begin{array}{c}\text { In-Migrating } \\
\text { Operating } \\
\text { Employees }\end{array}$ \\
\hline $\begin{array}{l}\text { Rural, sparsely populated, } \\
\text { no large trade center within } \\
\text { impact area }\end{array}$ & $0.3-0.5$ \\
$\begin{array}{l}\text { More urbanized, } \\
\text { moderate population } \\
\text { densities }\end{array}$ & $0.4-0.6$ \\
Fringe of metropolitan area & $0.6-0.8$
\end{tabular}

Bonneville determined a relationship between generation in aMW and coal mining 1 and use for four Pacific Northwest power plants (BPA 1988). On average, 0.23 acres are disturbed annually per MW of generation. Assuming a load factor of 0.85 results in 0.19 acres per MW capacity. The data used in the development of the estimate is presented in Table 3.18.

IABLE 3.18. Relationship between Power Generation and Land Use

\begin{tabular}{|c|c|c|c|}
\hline Power Plant & $\begin{array}{l}\text { Coal Consumption } \\
\text { (thousands of } \\
\text { tons per } M W \text { ) } \\
\end{array}$ & $\begin{array}{l}\text { Land Disturbance } \\
\text { (acres per year per } \\
\text { thousand tons of coal) } \\
\end{array}$ & $\begin{array}{c}\text { Land Disturbance } \\
\text { (acres per } \\
\text { year per } M W \text { ) }\end{array}$ \\
\hline Colstrip & 5.716 & 0.0187 & 0.1067 \\
\hline Boardman & 5.882 & 0.0170 & 0.1002 \\
\hline Centralia & 5.948 & 0.0588 & 0.3495 \\
\hline Bridger & 5.251 & 0.0664 & 0.3486 \\
\hline Average & 5.699 & 0.0402 & 0.226 \\
\hline
\end{tabular}





\subsection{ATMOSPHERIC FLUIDIZED BED COAL}

A summary of the impacts of the construction and operation of atmospheric fluidized bed coal (AFBC) plants on employment and land use is shown in Table 4.1. Sections 4.1 and 4.2 discusses these impacts.

TABLE 4.1. Resource Summary for Atmospheric Fluidized Bed Coal Plants

\begin{tabular}{|c|c|c|}
\hline & Employment $^{(a)}$ & Land Use ${ }^{(b)}$ \\
\hline Construction & 5.1 & 1.5 \\
\hline Operation & 0.7 & 0.2 \\
\hline
\end{tabular}

(a) Construction is in employee years per megawatt capacity; operation is in employees per year per megawatt capacity.

(b) Construction is in total acres disturbed per megawatt capacity; operation is in acres disturbed per year per megawatt capacity.

\subsection{CONSTRUCIION}

The construction schedule for an AFBC plant, the employment schedule, and the land-use impacts during construction are discussed below.

\subsubsection{Schedule and/or Duration}

Bonneville's Comparative Electric Generation Study (BPA 1987) estimates a six-year construction time for a 113-HW-capacity AFBC plant located in Boardman, Oregon (see Table 4.2). The construction period calculates to 1.6 months per MW capacity.

TABLE 4.2. Construction Cash Flow

$\begin{array}{cc}\text { Year } & \begin{array}{c}\text { Cumutative Percent of Total } \\ \text { Construction Expenditure }\end{array} \\ 1 & 0.1 \\ 2 & 8.0 \\ 3 & 26.0 \\ 4 & 73.0 \\ 5 & 95.0 \\ 6 & 100.0\end{array}$




\subsubsection{Direct Employment Schedule}

The same Bonneville study (1987) estimates direct construction employment to be $1,148,877$ manhours, or 10,167 manhours per MW capacity. The employment would be distributed over the life of the project in accordance with the above schedule. Assuming 2,000 hours in an employee-year, this works out to 5.08 employee years per megawatt capacity, exactly the same as was estimated for the pulverized coal plant from a collection of 14 sources.

\subsubsection{Construction Land-Use Impacts}

We calculated the land-use impacts to be approximately 1.5 acres per MW for an AFBC plant.

In its report, "Comparative Electric Generation Study: Coal-Fired Power Plants," (BPA 1987) Bonneville describes a 113-MW-capacity AFBC plant located in Boardman, Oregon, as requiring 150 acres, or 1.33 acres per MW capacity. An additional 100 acres would need to be prepared for the disposal of ash and scrubber sludge. This brings the total acreage requirement to 2.21 acres per MW capacity.

Alternatively, the Energy Technology Characterizations Handbook (DOE 1983) cites a 560-MW-capacity AFBC plant as requiring 442 acres, or 0.79 acres per MW capacity.

By averaging the figures from the DOE and Bonneville reports, we determined the impact to be 1.5 acres per MW.

\subsection{OPERATION}

Operations impacts for all types of coal generation include both the impacts directly attributable to the generating plant and the impacts attributable to the mining operation that supplies the coal. For an AFBC plant, 0.58 employees per $\mathrm{MW}$ are required to run the plant, and an additional 0.12 employees per MW are required for the mining operation, for a total operations requirement of 0.70 employees per MW capacity. The derivation of the estimates is described below. 


\subsubsection{Main Facility Direct Employment}

Bonneville's Comparative Electric Generation Study (BPA 1987) reported that a total of 66 employees are required to run an AFBC plant, or 0.58 operating employees per MW capacity. These employees are specified by skill mix in Table 4.3.

TABLE 4.3. Employee Mix for AFBC Plant

\begin{tabular}{|c|c|c|c|}
\hline 0\&M Labor Category & Iotal & $\begin{array}{l}\text { Employees } \\
\text { per MW }\end{array}$ & Percent \\
\hline Operators & 24 & 0.21 & $36 \%$ \\
\hline Maintenance & 21 & 0.18 & $32 \%$ \\
\hline Gate Security & 4 & 0.03 & $6 \%$ \\
\hline Laboratories/Stores & 4 & 0.03 & $6 \%$ \\
\hline General Help & 5 & 0.04 & $8 \%$ \\
\hline Supervisors & 8 & 0.07 & $12 \%$ \\
\hline Total & 66 & 0.58 & $100 \%$ \\
\hline
\end{tabular}

\subsubsection{Coal Mine Direct Employment}

The heat rate assumed by Bonneville for the AFBC plant is $9,885 \mathrm{Btu} / \mathrm{kWh}$. A mine employment estimate can be derived by assuming that the coal mine employment required by this type of plant will be less than that required by a conventional pulverized plant in accordance with the ratio of their heat rates. The pulverized $\mathrm{plant}$ has a heat rate of $10,856 \mathrm{Btu} / \mathrm{kWh}$ and requires 0.13 mine employees per MW of capacity, assuming a 0.8 capacity factor. The $A F B C$ plant can therefore be expected to require 0.12 employees per MW of capacity.

\subsubsection{Qperation Land-Use Impacts}

The operations land-use impacts consist of the land used by the coal mine supplying the plant. The land used to site the plant is discussed in Section 4.1.3.

The mine land area required is assumed to differ from that required by a conventional pulverized coal $\mathrm{plant}$ by the ratio of the heat rates. The heat rate for an AFBC plant is assumed by Bonneville to be $9,885 \mathrm{Btu} / \mathrm{Kwh}$, while the 
rate for a pulverized coal plant is assumed by Bonneville to be 10,856 $B t u / k W h$. A pulverized coal plant is estimated to require 0.19 acres per MW capacity per year (see Section 3.2.4). An AFBC plant should therefore require 0.17 acres per MW capacity per year. 


\subsection{COAL GASIFICATION}

A summary of the impacts of the construction and operation of integrated gasification combined-cycle (IGCC) plants on employment and land use is shown in Table 5.1. Sections 5.1 and 5.2 provide detailed discussions of how these impacts were determined.

TABLE 5.1. Resource Summary for Coal Gasification Plants

\begin{tabular}{|c|c|c|}
\hline & Employment ${ }^{(\theta)}$ & Land Use $\mathrm{e}^{(\mathrm{b})}$ \\
\hline Construction & 5.7 & 0.6 \\
\hline Operation & 0.9 & 0.2 \\
\hline
\end{tabular}

(a) Construction is in employee years per megawatt capacity; operation is in employees per year per megawatt capacity.

(b) Construction is in total acres disturbed per megawatt capacity; operation is in acres disturbed per year per megawatt capacity.

\subsection{CONSTRUCTION}

The construction schedule for an IGCC plant, the employment schedule, and the land-use impacts during construction are discussed below.

\subsubsection{Schedule and/or Duration}

The Comparative Electric Generation Study: Coal Gasification report (BPA 1986) estimates a 39-month construction time for a 451-MW-capacity IGCC coal plant located in Boardman, Oregon. A construction time of 0.09 months per MW capacity is calculated. The construction would proceed according to the schedule shown in Table 5.2 .

TABLE 5.2. Construction Cash Flow

Percent of Total

$\begin{array}{cc}\text { Year } & \text { Construction Expenditure } \\ 1 & 6.0 \% \\ 2 & 37.4 \% \\ 3 & 85.9 \% \\ 4 & 100.0 \%\end{array}$


The Office of Technology Assessment (1985) estimates 5 to 10 years construction time for a $700-\mathrm{MW}$-capacity plant, or 0.09 to.0.17 months per MW.

\subsubsection{Direct Employment Schedule}

Direct construction employment is estimated to be 5,114,000 manhours, or 11,339 manhours per MW capacity (BPA 1986). This is equivalent to 5.7 employee years per MW capacity, assuming a 2,000-hour employee year. The employment would be distributed over the life of the project in accordance with the above schedule.

\subsubsection{Construction Land-Use Impacts}

The Comparative Electric Generation Study: Coal Gasification report (BPA 1986) describes a 451-MW-capacity IGCC coal plant located in Boardman, Oregon, as requiring 150 acres upon completion of all four phases, resulting in a figure of 0.33 acres per MW capacity.

In a report for Congress, the Office of Technology Assessment estimates that a 625 -MW-capacity plant would require 300 to 600 acres, or 0.48 to 0.96 acres per MW capacity (OTA 1985).

Averaging the figures from these sources yields a land-use impact of 0.59 acres per $\mathrm{MH}$.

\subsection{OPERATION}

The total direct operation employment figure of 0.88 employees per MW was derived from the addition of the main facility direct employment figure $(0.77)$ and the coal mine direct employment figure (0.11). These figures are discussed below.

\subsubsection{Main Facility Direct Employment}

In its coal gasification report (BPA 1986), Bonneville specifies operating and maintenance costs for operating labor, maintenance labor, and administrative and support labor. Using the average salary for pulverized coal operation of $\$ 37,492$ (see the Appendix), an estimate of 0.77 operations employees per MW capacity per year can be derived. This data is presented in Table 5.3. All costs have been inflated to 1989 dollars using the GNP price 
deflator. For more detail on the assumptions used in these calculations, see Section 3.2.1.

TABLE 5,3. Operations Employment Mix Cost and Levels at a IGCC PIant

$\frac{\text { Labor Type }}{\text { Operating }}$

Maintenance

Admin. \& Support

Total

$\begin{array}{cc}\begin{array}{c}\text { Phase } 4 \\ \text { Cost } \\ (1989 \$ / \text { MW/yr })\end{array} & \begin{array}{c}\text { Employees per } \\ \text { MW Capacity } \\ \text { per yr }\end{array} \\ \$ 7,300 & 0.19 \\ \$ 14,767 & 0.39 \\ \$ 6,622 & 0.18 \\ \$ 28,689 & 0.77\end{array}$

\subsubsection{Coal Mine Direct Employment}

The heat rate assumed by Bonnevilile for the IGCC plant is 9,270 Btu/kWh. A mine employment estimate can be derived by assuming that the coal mine employment required by this type of plant will be less than that required by a conventional pulverized $\mathrm{plant}$ in accordance with the ratio of their heat rates. The pulverized plant has a heat rate of $10,856 \mathrm{Btu} / \mathrm{kWh}$ and requires 0.13 mine employees per MW of capacity, assuming a 0.85 load factor. The IGCC plant can therefore be expected to require 0.11 employees per MW of capacity.

\subsubsection{Operations Land-Use Impacts}

The operations land-use impacts consist of the land used by the coal mine required to supply the plant. The land used to site the plant is discussed in Section 5.1.3.

The mine land area required is assumed to differ from that required by a conventional pulverized $\mathrm{plant}$ by the ratio of the heat rates. The heat rate for a coal gasification plant is assumed by Bonneville to be 9,270 Btu/kWh, while the rate for a pulverized coal plant is assumed by Bonneville to be $10,856 \mathrm{Btu} / \mathrm{kWh}$. A pulverized coal plant is estimated to require 0.19 acres per MW capacity per year (see Section 3.2.4). A coal gasification plant should therefore require 0.16 acres per MW capacity per year. 
.

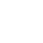




\subsection{COGENERATION}

A summary of the impacts of the construction and operation of cogeneration plants on employment and land use is shown in Table 6.1. Sections 6.1 and 6.2 provide detailed discussions of how these impacts were determined.

IABLE 6.1. Resource Sunmary for Cogeneration Plants

$$
\text { Employment }{ }^{(a)} \text { Land Use }{ }^{(b)}
$$

A11:

$\begin{array}{lcc}\text { Construction } & 15.1 & 1.7 \\ \text { Operation } & 4.5 & \text { NQ } \\ \text { WOOD-FIRED: } & & \\ \text { Construction } & 9.6 & 2.1 \\ \text { Operation } & 4.5^{(\mathrm{c})} & \text { NQ }\end{array}$

MUNICIPAL SOLID WASTE:

$\begin{array}{lrl}\text { Construction } & 24.1 & 1.6 \\ \text { Operation } & 4.5 & \mathrm{NQ}\end{array}$

(a) Construction is in employee years per megawatt capacity; operation is in employees per year per megawatt capacity.

(b) Construction is in total acres disturbed per megawatt capacity; operation is in acres disturbed per year per megawatt capacity.

(c) Estimate is for a MSW plant. No data for wood-fired plant employment were found.

NQ $=$ Not quantified.

\subsection{CONSTRUCTION}

The construction schedule for cogeneration plants, the employment schedule, and the land-use impacts during construction are discussed below.

\subsubsection{Schedule and/or Duration}

Estimates of the duration of construction for cogeneration plants vary widely. The full range of estimates is given below. 
In its report on Generating Resources Supply Curves (BPA 1985), Bonneville examined five cogeneration options: three wood-fired, one woodfired combustion turbine, and one municipal solid waste-fired (MSW). The wood-fired plants were all 12-MW capacity, and were projected to take 24 months to build. The wood-fired CT was 22-MW capacity, and expected to take 12 months to build. The MSW was 9.2-MW capacity and was expected to take 36 months to build. The months-per-MW figures for each plant are $0.5,1.8$, and .25 , respectively.

A Northwest Power Planning Council Staff Issue Paper on biomass resources (NWPPC 1989f) estimates a MSW incinerator with 2-MW capacity would take 18 months to build, or 9 months per MW.

The office of Technology Assessment (OTA 1985) estimates a 60 -MW-MSW plant would take 5 to 7 years to build or between 1.0 and 1.2 months per MW.

These estimates are summarized in Table 6.2.

TABLE 6.2. Construction Duration for Cogeneration Plants

\begin{tabular}{|c|c|c|c|c|}
\hline Type of Plant & $\begin{array}{l}\text { Capacity } \\
\text { (MW) } \\
\end{array}$ & $\begin{array}{c}\text { Months of } \\
\text { Construction }\end{array}$ & $\begin{array}{l}\text { Months } \\
\text { per MW }\end{array}$ & Source \\
\hline Wood fired & 12 & 24 & 2.0 & BPA 1985 \\
\hline Wood fired & 12 & 24 & 2.0 & BPA 1985 \\
\hline Wood fired & 12 & 24 & 2.0 & BPA 1985 \\
\hline Wood fired CT & 22 & 12 & 0.5 & BPA 1985 \\
\hline MSW & 9 & 36 & 4.0 & 8PA 1985 \\
\hline MSW & 2 & 18 & 9.0 & NWPPC $1989 \mathrm{f}$ \\
\hline MSW & 60 & $60-84$ & $1.0-1.4$ & OTA 1985 \\
\hline
\end{tabular}

\subsubsection{Direct Employment Schedule}

No explicit employment impact data are available for cogeneration plants. An ECO Northwest report (ECO Northwest et a 1.1986 ) predicts insignificant employment impacts from cogeneration plants fueled by mill waste, logging residue, and MSW-fueled cogeneration.

An extremely rough estimate of employment effects can be obtained through data on capital costs of various types of plants, given assumptions about the 
fraction of capital costs devoted to labor and the average construction labor wage rate. It was assumed that $20 \%$ of capital costs go to construction labor, a ratio that was developed as the average for a variety of coal technologies (BPA 1987; BPA 1986). The estimate will be off by the extent that cogeneration construction is more or less labor intensive than coal plant construction. In addition, the average pulverized coal plant salary of $\$ 37,492$ (see the Appendix) is used to derive the employee years per MW figures. Figures were inflated using the GNP price deflator to obtain 1989 figures. Table 6.3 shows the derivations.

IABLE 6.3. Employment Levels and Costs During Construction of a Cogeneration $\mathrm{Plant}$

\begin{tabular}{|c|c|c|c|c|}
\hline Plant Type & $\begin{array}{c}\text { Capacity } \\
\text { (MW) }\end{array}$ & $\begin{array}{c}\text { Capital } \\
\text { Cost } \\
1989 \$ / \mathrm{kW} \\
\end{array}$ & $\begin{array}{c}\text { Labor } \\
\text { Cost } \\
1989 \$ / \mathrm{MW}\end{array}$ & $\begin{array}{l}\text { Employee } \\
\text { Years } \\
\text { per MH } \\
\end{array}$ \\
\hline Wood fired & 12 & $\$ 1,207$ & $\$ 241,400$ & 6.4 \\
\hline Wood fired & 12 & $\$ 2,024$ & $\$ 404,800$ & 10.8 \\
\hline Wood fired & 12 & $\$ 2,905$ & $\$ 581,000$ & 15.5 \\
\hline Wood fired CT & 22 & $\$ 1,136$ & $\$ 227,200$ & 6.1 \\
\hline Wood/ag. Waste & 30 & $\$ 1,750$ & $\$ 350,000$ & 9.3 \\
\hline MSW & 9 & $\$ 4,102$ & $\$ 820,400$ & 21.9 \\
\hline MSW & 2 & $\$ 6,629$ & $\$ 1,325,800$ & 35.4 \\
\hline MSW & 60 & $\$ 2,841$ & $\$ 568,200$ & 15.1 \\
\hline Average & 19.9 & $\$ 2,824$ & $\$ 564,800$ & 15.1 \\
\hline Wood-Fired Avg & 17.6 & $\$ 1,804$ & $\$ 360,800$ & 9.6 \\
\hline MSW Average & 23.7 & $\$ 4,524$ & $\$ 904,800$ & 24.1 \\
\hline
\end{tabular}

\subsubsection{Construction Land-Use Impacts}

The construction land-use impacts from cogeneration consist of the land used to site the plant. Various sources (Baechler, Fickeisen, and Hendrickson 1990; ECO Northwest et al. 1986; OTA 1985) estimate the land required to site the plant at between 0.33 acres per MW and 5 acres per MW. The average being 1.7 acres. These estimates are given in Table 5.4. All sources agree that the plants would be located in industrial areas, limiting the land-use impacts from the siting of the plant. 
IABLE 6.4. Acreage Requirements for Siting a Cogeneration Plant

\begin{tabular}{lcccll} 
Type & Capacity & Acres & Acres/MW & \multicolumn{1}{c}{ Source } \\
Biomass & 12 & 25 & 2.1 & ECO Northwest et a1. 1986 \\
MSW & 10 & $10-50$ & $1-5$ & ECO Northwest et a1. 1986 \\
MSW & 10 & $10-15$ & $1-1.5$ & $\begin{array}{l}\text { Baechler, Fickeisen, and } \\
\text { Hendricksen 1990 }\end{array}$ \\
MSW & 60 & 20 & 0.3 & OTA 1985 \\
& 23 & $16-27$ & $1.1-2.2$ & \\
verage: & 12 & 25 & 2.1 & \\
ge: & 27 & $13-28$ & $0.8-2.3$ &
\end{tabular}

\subsection{OPERATION}

The employment and land-use impacts during operation of a cogeneration plant are discussed below.

\subsubsection{Direct Employment}

An ECO Northwest study (ECO Northwest et a1. 1986) estimates a 10-MW MSW plant would be operated by 45 employees and would displace some landfill employment. Ignoring the displacement effect results in 4.5 employees per MW capacity.

\subsubsection{Operation Land-Use Impacts}

The land-use impacts from operating a cogeneration plant include the impacts of the plant itself, and the impacts on the 1 and from supplying fuel for the plant. The impacts of the plant site itself are discussed in Section 6.1.3. The land-use impacts of supplying fuel to the plant vary depending on the type of plant. Biomass plants require the removal of logging or agricultural waste from the land for fuel, while MSW plants burn wastes that would otherwise be disposed of, most likely in a landfitl.

Biomass plants are cited (ECO Northwest et a1. 1986; 8aechler, Fickeisen, and Hendrickson 1990) as possibly reducing the productivity of forest 1 ands by removing nitrogen-supplying logging residue from the land, although Baechler 
(Baechler, Fickeisen, and Hendrickson 1990) states that only $10 \%$ to $25 \%$ of the fuel would come from logging residues, while the rest would come from mill waste.

6.5 



\subsection{COMBUSTION TURBINE}

A summary of the impacts of the construction and operation of combined cycle combustion turbine plants on employment and land use is shown in Table 7.1. Sections 7.1 and 7.2 provide detailed discussions of how these impacts were determined.

TABLE 7.1. Resource Summary for Combustion Turbine Plants

$\begin{array}{lccc} & \frac{\text { Employment }^{(a)}}{} & & \text { Land Use } \\ \text { Construction } & 1.4 & & 0.2 \\ \text { Operation } & 0.1 & \text { NQ }\end{array}$

(a) Construction is in employee years per megawatt capacity; operation is in employees per year per megawatt capacity.

(b) Construction is in total acres disturbed per megawatt capacity; operation is in acres disturbed per year per megawatt capacity.

NQ $=$ Not quantified.

\subsection{CONSTRUCTION}

The construction schedule for combustion turbine plants, the employment schedule, and the land-use impacts during construction are discussed below.

\subsubsection{Schedule and/or Duration}

Several sources provide estimates on the duration of construction of a combustion turbine plant. These estimate range from 18 to 39 months or 0.08 to 0.20 months per MW capacity. The various estimates are given in Table 7.2.

A report published by Fluor provides a schedule for construction of a combined-cycle plant (Fluor Daniel, Inc. 1988). The schedule is presented in Table 7.3 . 
TABLE 7.2. Construction Duration for Combustion Turbine Plants

\begin{tabular}{|c|c|c|c|c|}
\hline Type & $\begin{array}{l}\text { Capacity } \\
\text { (MW) }\end{array}$ & $\begin{array}{l}\text { Months of } \\
\text { Construction }\end{array}$ & $\begin{array}{l}\text { Months } \\
\text { per MW }\end{array}$ & Source \\
\hline CC & 452.2 & 39 & 0.09 & Fluor Daniel Inc. 1988 \\
\hline CC & 452 & 36 & 0.08 & NWPPC 1989a \\
\hline-- & 150 & 18 & 0.12 & $\begin{array}{l}\text { Baechler, Fickeisen, \& } \\
\text { Hendrickson } 1990\end{array}$ \\
\hline-- & 150 & 30 & 0.20 & OTA 1985 \\
\hline CC & 321 & 36 & 0.11 & BPA 1985 \\
\hline SC & 304 & 24 & 0.08 & NWPPC 1989a \\
\hline SC & 236 & 24 & 0.10 & BPA 1985 \\
\hline verage & 295 & 30 & 0.11 & \\
\hline
\end{tabular}

$C C=$ combined-cycle combustion turbine

$S C=$ simple-cycle combustion turbine

IA8LE 7.3. Construction Schedule for a Combined-Cycle Combustion Turbine Plant

\begin{tabular}{|c|c|c|c|c|c|}
\hline \multirow[b]{2}{*}{ Month } & \multicolumn{4}{|c|}{$\begin{array}{l}\text { Cumulative Cash Flow } \\
\text { (Millions of } 1988 \$ \text { ) }\end{array}$} & \multirow[b]{2}{*}{ Percent } \\
\hline & Phase 1 & Phase 2 & Phase 3 & $\underline{\text { Total }}$ & \\
\hline $\begin{array}{r}3 \\
6 \\
9 \\
12 \\
15 \\
18 \\
21 \\
24 \\
27 \\
30 \\
33 \\
36 \\
39\end{array}$ & $\begin{array}{r}0.4 \\
15.5 \\
26.9 \\
38.9 \\
51.1 \\
68.6 \\
76.4 \\
81.2 \\
82.2 \\
90.4 \\
95.9 \\
100.0 \\
102.3\end{array}$ & $\begin{array}{l}8.6 \\
15.2 \\
21.8 \\
28.9 \\
39.2 \\
42.7 \\
46.0 \\
69.8 \\
-- \\
-- \\
-- \\
-- \\
--\end{array}$ & $\begin{array}{l}0.3 \\
3.7 \\
10.3 \\
18.2 \\
28.1 \\
40.0 \\
54.4 \\
-. \\
-- \\
-- \\
-- \\
-- \\
--\end{array}$ & $\begin{array}{r}9.3 \\
34.4 \\
59.0 \\
86.0 \\
118.4 \\
151.3 \\
176.8 \\
205.4 \\
206.4 \\
214.6 \\
220.1 \\
224.2 \\
226.5\end{array}$ & $\begin{array}{r}4.1 \% \\
15.2 \% \\
26.0 \% \\
38.0 \% \\
52.3 \% \\
66.8 \% \\
78.1 \% \\
90.7 \% \\
91.1 \% \\
94.7 \% \\
97.2 \% \\
99.0 \% \\
100.0 \%\end{array}$ \\
\hline Year & Total & Percent & & & \\
\hline $\begin{array}{l}1 \\
2 \\
3 \\
4\end{array}$ & $\begin{array}{r}86.0 \\
205.4 \\
224.2 \\
226.5\end{array}$ & $\begin{array}{r}38.0 \% \\
90.7 \% \\
99.0 \% \\
100.0 \%\end{array}$ & & & \\
\hline
\end{tabular}




\subsubsection{Direct Employment Schedule}

Fluor estimates total labor expenditures for construction of a combinedcycle combustion turbine to be $\$ 25,119,791$ in 1989 dollars, and to require $1,290,000$ manhours (Fluor Daniel, Inc. 1988). These translate to $\$ 55,550$ per MW and 2,853 manhours per MW for a 452.2-MW-capacity plant. Assuming a 2,000hour employee year results in an estimate of 1.4 employee years per MW capacity.

\subsubsection{Construction Land-Use Impacts}

Three sources provide estimates for land-use impacts. These siteconstruction land-use impacts consist of the area required to site the plant. The estimates of plant area are given in Table 7.4. The average is 0.16 acres per MW capacity.

TABLE 7.4. Acreage Requirements for Siting a Combined-Cycle Combustion Turbine Plant

\begin{tabular}{|c|c|c|c|}
\hline $\begin{array}{l}\text { Capacity } \\
\text { (MW) }\end{array}$ & $\begin{array}{c}\text { Area } \\
\text { (acres) }\end{array}$ & $\begin{array}{l}\text { Acres } \\
\text { per MW }\end{array}$ & Source \\
\hline 452 & 75 & 0.17 & Fluor Daniel, Inc. 1988 \\
\hline 150 & $2-5$ & $0.01-0.03$ & OTA 1985 \\
\hline 150 & 44 & 0.29 & Baechler, Fickeisen \& Hendrickson 1990 \\
\hline
\end{tabular}

\subsection{OPERATION}

The employment and land-use impacts resulting from operation of a combustion turbine plant are discussed below.

\subsubsection{Direct Employment}

Fluor supplies the most detailed source for operations employment figures in its report, Development of Combustion Turbine Capital and Operating Costs, (Fluor Daniel, Inc. 1988), which estimates a completed combined-cycle combustion turbine plant will require 0.07 operating employees per MW capacity (see Table 7.5). 
IABLE 7.5. Employment Levels for Operation of a Combined-Cycle Combustion Turbine Plant

\begin{tabular}{|c|c|c|c|c|}
\hline Labor & Numl & of Empl & yees & Phase 3 Employees \\
\hline Category & Phase 1 & Phase 2 & Phase 3 & per $\mathrm{MW}, 452.2 \mathrm{MW}$ \\
\hline Operating Crew & 2 & 3 & 20 & 0.04 \\
\hline Maintenance Crew & 2 & 3 & 9 & 0.02 \\
\hline Administrative & 1 & 2 & 3 & 0.01 \\
\hline Security & 0 & 0 & 1 & 0.00 \\
\hline Total Staff & 5 & 8 & 33 & 0.07 \\
\hline
\end{tabular}

The Fluor report (FIuor Daniel, Inc. 1988) also contains data on the fixed costs incurred by the plant and the labor portion thereof, shown here in Table 7.6. Fluor indicates that variable costs contain no labor component.

IABLE 7.6. Fixed Costs for Operation of a Combined-Cycle Combustion Turbine Plant

\begin{tabular}{|c|c|c|c|}
\hline \multirow[b]{2}{*}{ Fixed Costs } & \multicolumn{3}{|c|}{$\begin{array}{l}12 \text { Months Base Load Costs } \\
\text { (in thousands of } 1988 \$ / y r)\end{array}$} \\
\hline & Phase 1 & Phase 2 & Phase 3 \\
\hline Operating Labor & 116 & 175 & 1,165 \\
\hline Maintenance Labor & 116 & 175 & 525 \\
\hline Maintenance Material & 132 & 263 & 788 \\
\hline Administrative \& Support Labor & 58 & 116 & 216 \\
\hline Total Fixed Costs: & 422 & 729 & 2,694 \\
\hline Labor Portion: & $69 \%$ & $64 \%$ & $71 \%$ \\
\hline
\end{tabular}

\subsubsection{Operation Land-Use Impacts}

Land-use impacts of operation consist of the area used by the site and the impacts associated with the production and delivery of natural gas. The impacts of the site are discussed above, and there are no data on the impacts of the production and delivery of natural gas. 


\subsection{GEOTHERMAL}

A summary of the impacts of the construction and operation of geotherma? systems on employment and land use is shown in Table 8.1. Sections 8.I and 8.2 provide detailed discussions of how these impacts were determined.

TABLE 8.1. Resource Summary for Geothermal Systems

\begin{tabular}{|c|c|c|c|}
\hline \multirow{2}{*}{\multicolumn{2}{|c|}{ Construction }} & Employment ${ }^{(a)}$ & $\underline{\text { Land } U s e^{(b)}}$ \\
\hline & & 4.1 & 0.2 \\
\hline Oper & tion & 0.3 & NQ \\
\hline (b) & \multicolumn{3}{|c|}{$\begin{array}{l}\text { Construction is in employee years per megawatt } \\
\text { capacity; operation is in employees per year per } \\
\text { megawatt capacity. } \\
\text { Construction is in total acres disturbed per megawatt } \\
\text { capacity; operation is in acres disturbed per year } \\
\text { per megawatt capacity. }\end{array}$} \\
\hline
\end{tabular}

\subsection{CONSTRUCTION}

The construction schedule for geothermal plants, the employment schedule, and the land-use impacts during construction are discussed below.

\section{1 .1 Schedule and/or Duration}

Geothermal power is developed in incremental stages, so that capacity is brought on-line throughout a long construction period. A number of sources provide data on construction duration. Note non-construction downtime (four winter months per year) is included in the duration estimate (i.e., a project taking three 8 -month seasons to build has a duration of 36 months).

\subsubsection{Direct Employment Schedule}

The Worldwatch Institute Report (Flavin and Lenssen 1990) estimates that geothermal power results in 112 jobs per 1,000 gigawatt-hours per year. This is an annual average, including both construction and operation. 
TABLE 8.2. Construction Duration for Geothermal Systems

\begin{tabular}{|c|c|c|c|c|}
\hline Source & $\begin{array}{l}\text { Capacity } \\
\text { (MW) }\end{array}$ & Iype $e^{(a)}$ & $\begin{array}{l}\text { Duration } \\
\text { (months) }\end{array}$ & $\begin{array}{l}\text { Months } \\
\text { per MW }\end{array}$ \\
\hline OTA 1985 & 53 & Flash & $36-60$ & $0.7-1.1$ \\
\hline OTA 1985 & 70 & Binary & $36-60$ & $0.5-0.9$ \\
\hline OTA 1985 & 10 & Binary & 12 & 1.2 \\
\hline USDA 1979 & 100 & NA & $84-120$ & $0.8-1.2$ \\
\hline USDA 1979 & 1000 & NA & $120-240$ & $0.1-0.2$ \\
\hline Geyer 1988 & 100 & NA & $36-60$ & $0.4-0.6$ \\
\hline NWPPC $1989 \mathrm{~h}$ & 50 & NA & 36 & 0.7 \\
\hline NWPPC $1989 \mathrm{~h}$ & 25 & NA & 28 & 1.1 \\
\hline NWPPC $1989 \mathrm{~h}$ & 10 & NA & 16 & 1.6 \\
\hline CEC 1983 & 2246 & NA & 146 & 0.1 \\
\hline CEC 1983 & 3000 & NA & 192 & 0.1 \\
\hline BPA 1985 & 1 & Binary & 4 & 4 \\
\hline BPA 1985 & 8.4 & Binary & 84 & 10 \\
\hline BPA 1985 & 11.6 & Flash & 72 & 6.2 \\
\hline BPA 1985 & 10.7 & Binary & 72 & 6.7 \\
\hline BPA 1985 & 5.6 & NA & 48 & 8.6 \\
\hline Average & 419 & $-\cdot$ & 71 & 0.17 \\
\hline
\end{tabular}

NA = Information not available.

(a) A binary geothermal system is a two-phase system that transfers Tower temperature geothermal heat to a secondary heat transfer fluid. A flash system converts higher temperature (150 to $280^{\circ} \mathrm{C}$ ) geothermalty heated water to steam for electricity production.

A variety of sources contain data on the construction employment requirements of geothermal plants. Estimates range from 1.2 to 6.9 employee years per MW capacity. An average value of 4.1 employee years per MW capacity will be used. The various estimates are described below.

A report issued by the U.S. Department of Agriculture (USDA 1979) uses data derived from the Geysers experience in California. This report states that a 1,000-MW facility is assumed to take 10 to 20 years to develop and average 150 to 300 employees in the development stage. These figures provide a range of between 1.4 and 6 employee years per MW capacity. 
Geyer (1988) estimates that during the two to three 8-month construction seasons, 70 to 100 workers may be on the job, with 20 more elsewhere. For the $100-M W$ plant, calculations render figures ranging from 1.2 to 2.4 employee years per MW capacity.

ECO Northwest et al. (1986) reports that the employment impacts of building a 10-MW geothermal facility would be insignificant.

A study done by the California Energy Commission (1983) estimates a 2,246-MW facility would require 15,141 construction employee years $(6.7$ per MW), while a 3,000-MW facility would require 20,706 employee years (6.9 per MW).

\subsubsection{Construction Land-Use Impacts}

Construction land-use impacts consist of the area required to site the plant. The following two sources present a large range of acreage requirements, stating that the range is much narrower if restricted to just the plant site. While it is important to include areas beyond the plant site (such as roads and transmission lines), no data on these areas have been located for the other resources. For this reason, an estimate of 0.2 acres per MW capacity has been chosen as best representing the data below.

The ECO Northwest report (ECO Northwest et a1. 1986) states that the land-use impacts would be insignificant.

Geyer (1988) estimates a 100-MW plant would require development of 160 acres of a 1,280-acre area, or 1.6 acres per MW capacity out of 128 acres per MW capacity. The land-use would consist of

20 acres for plant site

60 acres for roads and pipelines

60 acres for 20 three-acre drill pads

10 to 20 acres for power-line right-of-way.

In a report on new electric power technologies, the OTA (1985) presented estimates of land-use requirements for three types of geothermal plants (see Table 8.3). 
IABLE 8.3. Acreage Requirements for Geothermal Plants

\begin{tabular}{|c|c|c|c|}
\hline $\begin{array}{l}\text { Plant } \\
\text { Iype } \\
\end{array}$ & $\begin{array}{l}\text { Capacity } \\
\text { (MW) }\end{array}$ & $\begin{array}{l}\text { Land Use } \\
\text { (acres) }\end{array}$ & $\begin{array}{l}\text { Acres } \\
\text { per MW } \\
\end{array}$ \\
\hline Flash & 53 & $8-20$ & $0.15-0.38$ \\
\hline Binary & 70 & $8-20$ & $0.11-0.29$ \\
\hline Binary & 10 & $1-3$ & $0.10-0.30$ \\
\hline Average & 44.3 & $5.7-14$ & $0.12-0.32$ \\
\hline
\end{tabular}

\subsection{OPERATION}

The employment impacts resulting from operation of a geothermal plant are discussed below.

\subsubsection{Direct Employment}

A USDA study (1979) estimates a 100-MW plant requires 10 people for plant operation, well maintenance, and pipeline maintenance, while steam production will require one drilling rig with a 20 -man complement. The USDA study also estimates a 500-MW facility would require 100 to 150 employees, and a l,000-MW facility would require 200 to 300 employees. The California Energy Commission (1983) estimates 15,200 08M employee-years for a 2,246-MW facility (6.8 per MW), and 15,660 for a 3,000-MW facility (5.2 per MW). Assuming a 20-year life provides a range of estimates from 0.26 to 0.34 operators per MW per year, averaging 0.28 . These data are summarized below.

IABLE 8.4. Employment Levels for Geothermal Plants

\begin{tabular}{|c|c|c|}
\hline $\begin{array}{c}\text { Plant } \\
\text { Capacity } \\
(M W) \\
\end{array}$ & $\begin{array}{l}\text { Number of } \\
\text { Employees }\end{array}$ & $\begin{array}{c}\text { Employees } \\
\text { per MW per yr }\end{array}$ \\
\hline 100 & 30 & 0.3 \\
\hline 500 & $100-150$ & $0.2-0.3$ \\
\hline 1,000 & $200-300$ & $0.2-0.3$ \\
\hline 2,246 & 760 & 0.34 \\
\hline 3,000 & 783 & 0.26 \\
\hline 1,369 & 375 & $0.26-0.30$ \\
\hline
\end{tabular}


As a note of caution, Geyer (1988) states that the jobs-per-megawatt ratio varies with total plant size, because operating crews do not grow proportionally. The report describes existing facilities of 25 to $80 \mathrm{MW}$ capacity as needing 25 to 35 permanent staff to operate. A 10-MW plant requires 20 people, with an additional 10 in the well field. The skill mix is as follows:

9 operators

4 maintenance mechanics

2 engineers

2 clerks

1 secretary

1 plant supervisor

2 to 5 temporary laborers

8 permanent well-field employees

2 temporary well-field employees

contract drillers.

The ECO Northwest study (ECO Northwest et a1. 1986) states there would be no impact from the operations employment of a $10-M W$ geothermal plant.

\subsubsection{Operation Land-Use Impacts}

Land-use impacts are discussed in Section 8.1.3. 


\section{$9.0 \underline{\text { HYDRO }}$}

A summary of the impacts of the construction and operation of hydro electric facilities on employment and land use is shown in Table 9.1. Sections 9.1 and 9.2 provide detailed discussions of how these impacts were determined. The hydro designations in the table (Hydro 1, 2, 3, and 4) refer to generic cost categories that are described in the 1990 Bonnevitle Resource Program (BPA 1990). New Hydro 1 is the least expensive per unit of capacity; New Hydro 4 is the most expensive. These categories reflect generic groups of hydro facilitities and not specific projects.

TABLE 9.1. Resource Summary for Hydro Electric Facilities

\begin{tabular}{|c|c|c|}
\hline & Employment ${ }^{(\mathrm{a})}$ & Land Use \\
\hline $\begin{array}{l}\text { Construction } \\
\text { Operation }\end{array}$ & $\begin{array}{l}9.3 \\
0.3\end{array}$ & $\begin{array}{l}\text { NQ } \\
\text { NQ }\end{array}$ \\
\hline
\end{tabular}

Hydro Efficiency Improvements:

Construction

Operation

$\begin{array}{cc}\frac{\text { Employment }}{(a)} & \frac{\text { Land } \text { Use }^{(b)}}{4.9} \\ 0.0 & 0\end{array}$

New Hydro 1:

Construction

Operation

$$
\begin{array}{cc}
\frac{\text { Employment }}{(\mathrm{a})} & \text { Land Use } \\
8.3 & \text { NQ } \\
0.2 & \text { NQ }
\end{array}
$$

New Hydro 2:

Construction Operation

$$
\frac{\text { Employment }^{(a)}}{10.4} \quad \frac{\text { Land Use }}{\text { (b) }}
$$

New Hydro 3:

Construction Operation

$\begin{array}{cc}\frac{\text { Employment }}{(8)} & \frac{\text { Land Use }}{(b)} \\ \begin{array}{c}\text { LQ } \\ 0.3\end{array} & \text { NQ }\end{array}$

New Hydro 4:

Construction Operation

\footnotetext{
(a) Construction is in employee years per megawatt capacity; operation is in employees per year per megawatt capacity.

(b) Construction is in total acres disturbed per megawatt capacity; operation is in acres disturbed per year per megawatt capacity.

NQ = Not quantified.
} 


\subsection{CONSTRUCTION}

The construction schedule for hydro electric facilities, the employment schedule, and the land-use impacts during construction are discussed below.

\subsubsection{Schedule and/or Duration}

Numerous sources present scheduling data on construction of hydro electric facilities. A summary of the data is presented below in Table 9.2.

IABLE 9.2. Construction Duration for Hydro Electric Facilities

\begin{tabular}{lccc} 
Source & $\begin{array}{c}\text { Capacity } \\
(M W)\end{array}$ & $\begin{array}{c}\text { Duration } \\
\text { (months) }\end{array}$ & $\begin{array}{c}\text { Months } \\
\text { per Mw }\end{array}$ \\
\cline { 2 - 2 } & 1 & 24 & 24 \\
BPA 1990 & 10 & 36 & 3.6 \\
NWPPC 1989a & 190 & 36 & 0.19 \\
NWPPC 1989a & 290 & 36 & 0.12 \\
NWPPC 1989a & 340 & 36 & 0.11 \\
NWPPC 1989a & 240 & 36 & 0.15
\end{tabular}

\subsubsection{Direct Employment Schedule}

The only specific employment data located were found in a Charles River Associates report (1984), which cites a figure of 5 to 15 employee years per one million 1983 dollars spent on construction. The large range is caused by differences in the sizes of hydro plants. Using the GNP price deflator and assuming no changes in construction labor productivity, these figures calculate a range of 4.2 to 12.5 employee years per one million 1989 dollars in construction costs. The midpoint of this range, 8.4 employee years per million dollars in capital costs, will be used in this analysis.

Capital cost estimates per MW capacity (NWPPC 1989a) and estimates for efficiency improvements (BPA 1985) for new hydro facilities can be used in conjunction with the employee years estimate chosen above to calculate estimates of construction employment per MW of generation capacity. Table 9.3 presents these concepts (capital costs inflated to 1989 \$ using the GNP price deflator). 
TABLE 9.3. Capital Costs and Employment Levels for Construction of Hydro Facilities

New Hydro Facilities:

\begin{tabular}{|c|c|c|c|}
\hline Resource & $\begin{array}{c}\text { Capacity } \\
(M W) \\
\end{array}$ & $\begin{array}{c}\text { Capital } \\
\text { Costs } \\
(1989 \$ / \mathrm{kW}) \\
\end{array}$ & $\begin{array}{c}\text { Employee Years } \\
\text { per MW Capacity } \\
\text { (years/MW) }\end{array}$ \\
\hline New Hydro 1 & 190 & 985 & 8.3 \\
\hline New Hydro 2 & 290 & 1,240 & 10.4 \\
\hline New Hydro 3 & 340 & 1,700 & 14.3 \\
\hline New Hydro 4 & 240 & 2,060 & 17.3 \\
\hline Average: & 265 & 1,496 & 12.6 \\
\hline
\end{tabular}

Efficiency Improvements:

\begin{tabular}{|c|c|c|c|}
\hline Resource $^{(a)}$ & $\begin{array}{c}\text { Capacity } \\
(M W)\end{array}$ & $\begin{array}{c}\text { Capital } \\
\text { Costs } \\
(1989 \$ / \mathrm{kW}) \\
\end{array}$ & $\begin{array}{c}\text { Employee Years } \\
\text { per MW Capacity } \\
\text { (years/MW) }\end{array}$ \\
\hline Kaplan Governor & 0.5 & 91 & 0.8 \\
\hline Francis Runner & 1.0 & 568 & 4.8 \\
\hline Kaplan Runner & 1.0 & 1,079 & 9.1 \\
\hline Average: & 0.8 & 579 & 4.9 \\
\hline
\end{tabular}

(a) Kaplan governors and Francis and Kaplan runners are mechanical improvements that increase hydro facility efficiency.

This analysis estimates an average of 12.6 employee years per MW of new hydro capacity, and 4.9 employee years per MW of capacity from hydro efficiency improvements.

These same capital cost figures were adopted by Bonneville in the 1990 Resource Program (BPA 1990).

\subsubsection{Construction Land-Use Impacts}

While improvements in the efficiency of existing hydro facilities would not result in any land-use impacts, new hydro facilities could easily result in extensive land-use impacts. Impacts would be expected due to flooding and potential changes in river flow patterns. The land-use impacts from new hydro facilities will vary considerably according to the specifics of a particular project. The Department of Energy's Energy Technology Characterizations 
Handbook (DOE 1983) describes a 357-MW-capacity run-of-river (i.e., no storage capacity) hydropower dam as requiring 397 acres, or 1.11 acres per MW capacity. This area consists only of the dam. However, it should be noted that this figure does not include any area flooded by the dam. Because of the sensitivity of the land-use impact to the specifics of the project, no further attempt to quantify the land-use impacts will be undertaken.

\subsection{OPERATION}

The employment impacts resulting from operation of a hydro facility are discussed below.

\subsubsection{Direct Employment}

Hydropower efficiency improvements are assumed to require no additional operations or maintenance employees.

DOE's Technology Characterizations Handbook (DOE 1983) describes a 357 MW-capacity run-of-river hydropower dam as requiring 16.8 employees. This calculates to 0.05 employees per MW capacity.

Another method of determining the operations labor requirements of a new hydropower facility is to back it out of an estimate of the fixed 0\&M expenditures per MW capacity. Bonneville's 1990 Resource Program Technical Report (BPA 1990) estimates a new small hydro facility as having annual 08M expenditures of $\$ 33,579$ per MW capacity, in 1989 dollars. This is an average of the four new hydropower alternatives. The average labor fraction of 0\&M expenditures over six technologies (pulverized coal, AFBC, IGCC, CCCT, SCCT, and nuclear) is $56 \%$ (see the Appendix for supporting data and documentation). This implies 0\&M labor expenditures of \$18,804 per MW capacity, in 1989 dollars. Assuming an average 0\&M worker salary of $\$ 37,492$ (the pulverized coal figure cited in BPA 1987) results in 0.50 08M employees per MW capacity. The figure of $0.2808 \mathrm{M}$ employees per MW capacity, which is the average of this estimate and the 0.05 developed from DOE 1983, will be used for the overall average. Estimates for each of the four alternatives are shown in Table 9.4. 
IABLE 9.4. Labor Requirements for Hydro Facility Operation

\begin{tabular}{|c|c|c|c|c|}
\hline Resource & $\begin{array}{c}\text { Capacity } \\
\text { (MW) } \\
\end{array}$ & $\begin{array}{c}\text { Fixed } 08 M \\
(1989 \mathrm{~S} / \mathrm{kW})\end{array}$ & $\begin{array}{l}\text { Employees } \\
\text { per MW }\end{array}$ & $\begin{array}{l}\text { Average } \\
\text { Employees } \\
\text { Der MW (a) }\end{array}$ \\
\hline New Hydro 1 & 10 & 22 & 0.33 & 0.19 \\
\hline New Hydro 2 & 10 & 28 & 0.42 & 0.24 \\
\hline New Hydro 3 & 10 & 39 & 0.58 & 0.32 \\
\hline New Hydro 4 & 10 & 46 & 0.69 & 0.37 \\
\hline Average & 10 & 33.8 & 0.50 & 0.28 \\
\hline
\end{tabular}

(a) After averaging estimate for each hydro package and 0.05 from DOE 1983.

\subsubsection{Operation Land-Use Impacts}

Land-use impacts resulting from new hydro facilities are discussed in Section 9.1.3. 



\section{$10.0 \quad$ SOLAR}

A sumnary of the impacts of the construction and operation of solar energy systems on employment and land use is shown in Table 10.1. Sections 10.1 and 10.2 provide detailed discussions of how these impacts were determined.

IABLE 10.1. Resource Summary for Solar Energy Systems

$\begin{array}{lcc} & \text { Employment } & \\ \text { Construction } & 19.6 & \frac{\text { Land Use }}{(b)} \\ \text { Operation } & 0.4 & 3.6\end{array}$

(a) Construction is in employee years per megawatt capacity; operation is in employees per year per megawatt capacity.

(b) Construction is in total acres disturbed per megawatt capacity; operation is in acres disturbed per year per megawatt capacity.

\subsection{CONSTRUCTION}

The construction schedule for solar plants, the employment schedule, and the 1 and-use impacts during construction are discussed below.

\subsection{Schedule and/or Duration}

The report by the Office of Technology Assessment (OTA 1985) estimates a 10-MW central photovoltaic station takes 2 years to build whether it is a flat-plat or concentrator type station. This works out to 0.41 months per MW.

The Northwest Power Planning Council study (NWPPC 1989b) estimates a 80MW parabolic trough with gas backup takes 1 year to construct, or 0.15 months per MW.

Bonneville (BPA 1985) estimates the duration for construction of a $100-M W$ facility, both thermal and photovoltaic, to be 32 months, or 0.32 months per MW. 


\subsubsection{Direct Employment Schedule}

A study by DOE (1981) estimates 17.1 employee years per quadrillion Btu for a photovoltaic plant. This figure includes construction and 08M employees. DOE estimates 22.7 employee years per quadrillion Btu for a central thermal plant.

The Worldwatch report (Flavin and Lenssen 1990) estimates that solar thermal electricity generation provides 248 jobs per thousand gigawatt-hours annually. The figure includes both construction and operation.

The Solar Energy Research Institute (SERI 1989) estimated that in 1987, a remote stand-alone $1-\mathrm{kW}$ system cost $\$ 10,660$. Within this figure, $\$ 1,500(14 \%)$ was for labor. They also estimated the total cost for a large, installed grid-tied $1-k W$ system at $\$ 7,000$, of which $\$ 1,000$ (14\%) was for labor. SERI projected that costs for both systems would fall by the year 2000 (as shown in Table 10.2). In 1989 dollars, a grid-tied system would have labor costs of $\$ 1,075,269$ per MW capacity (calculated from figures in Table 10.2). Using an average construction worker salary of $\$ 34,496$ (See the Appendix) results in 31.2 construction employee years per MW capacity.

DOE's Technology Characterization Handbook (DOE 1983) estimates a 200-MWcapacity solar thermal plant would require 850 to 1,270 construction employees annually, on average, for a 2- to 3-year period. This results in a range of 1,700 to 3,810 employee years, or 8.5 to 19.1 employee years per MW capacity.

TABLE 10.2. Labor Costs for Construction of Solar Generation Systems

\begin{tabular}{|c|c|c|c|}
\hline \multirow{2}{*}{\multicolumn{4}{|c|}{$\left.\frac{1990}{\text { System }} \frac{1995}{(1987} \mathrm{S} / \mathrm{kW}^{(0)}, \mathrm{DC}\right): 2000$}} \\
\hline & & & \\
\hline Labor & $\$ 1,000$ & $\$ 800$ & $\$ 500$ \\
\hline Total & $\$ 7,550$ & $\$ 5,350$ & $\$ 4,050$ \\
\hline Labor Percent & $13 \%$ & $15 \%$ & $12 \%$ \\
\hline
\end{tabular}

Large, Installed, Grid-Tied System (1987\$/kWp, AC):

Labor

Total

Labor Percent
$\$ 800$

$\$ 5,500$

$15 \%$
$\$ 500$

$\$ 2,900$

$17 \%$
$\$ 300$

$\$ 2,100$

$14 \%$

(a) Killowatts potential capacity 
The same source estimates a solar photovoltaic plant of 109 MW capacity would require 850 construction employees, or 7.8 per megawatt capacity. No construction duration is given, so the same time frame, 2 to 3 years, is assumed. This results in 15.6 to 23.4 employee years per MW capacity.

The five estimates of construction employment requirements given above average to 19.6 employee years per MW capacity.

\subsubsection{Construction Land-Use Impacts}

A wide number of estimates were located to assess the land-use impacts. Upon consideration, the DOE figure of 3.6 acres per MW was chosen as the most applicable (DOE 1983). The construction land-use impacts consist of the area required by the site.

Baechler, Fickejsen, and Hendrickson (1990) estimate a central station solar plant may require 1,000 to 1,500 acres of 1 and. An ECO Northwest report (ECO Northwest et al. 1986) also predicts 1,000 to 1,500 acres will be required, and calls this impact significant.

The OTA (1985) has estimates for various facilities. These estimates are presented in Table 10.3 .

TABLE 10.3. Acreage Requirements for Solar Plants

\begin{tabular}{lcccc} 
System Type & $\begin{array}{c}\text { Capacity } \\
(M W)\end{array}$ & & $\begin{array}{c}\text { Land } \\
\text { (acres) }\end{array}$ & $\begin{array}{c}\text { Acres } \\
\text { der MW }\end{array}$ \\
\cline { 2 - 2 } PV - Flatplate & 10 & & $40-370$ & $4-37$ \\
PV - Concentrator & 10 & & $60-320$ & $6-32$ \\
Thermal - Parabolic & 0.075 & & 67 & 893 \\
Thermal - Central Rec. & 10.8 & & 700 & 65 \\
Average & 7.7 & & $217-364$ & $242-257$ \\
PV Average & 10 & & $50-345$ & 5 \\
Thermal Average & 5.4 & & 384 & 479 \\
& & & & \\
PV = photovoltaic & & &
\end{tabular}


DOE's Technology Characterization Handbook (DOE 1983) estimates a 200MW-capacity solar thermal plant would require 1,000 acres, or 5 acres per MW capacity. These figures average to 3.6 acres per MW.

\subsection{OPERATION}

The employment impacts resulting from operation of a solar plant are discussed below.

\subsubsection{Direct Employment}

DOE (1983) estimates a 200-MW-capacity solar thermal plant would require 60 08M employees, or 0.30 per MW capacity.

Another method of determining the operations labor requirements of a solar facility follows that outlined in Section 10.2.1. Estimates of fixed O8M costs for solar facilities are given in three sources (BPA 1985; DOE 1983; and NWPPC 1989b). These sources estimate that a photovoltaic plant has average 08M costs of $\$ 27,229$ in 1989 dollars annually, while a solar thermal plant would have average annual 08M charges of $\$ 33,400$ (see the Appendix for the development of these averages). Using an average 08M labor fraction of 0.56 and an average operator salary of $\$ 37,492$ (see Section 10.2.1) results in an estimate of 0.41 08M employees per MW capacity for a solar photovoltaic $\mathrm{plant}$ and $0.5008 \mathrm{M}$ employees per $\mathrm{MW}$ for a solar thermal plant. The average of these two estimates is 0.46 .

The figure used is the average of the DOE (1983) figure and $(0.46)$. This average amounts to 0.4 employees per MW.

\subsubsection{Operation Land-Use Impacts}

The land-use impacts are discussed in Section 10.1.3. 


\section{$11.0 \underline{\text { WIND }}$}

A summary of the impacts of the construction and operation of wind energy facilities on employment and land use is shown in Table 11.1. Sections 11.1 and 11.2 provide detailed discussions of how these impacts were determined.

TABLE 11.1. Resource Summary for Wind Energy Facilities

\begin{tabular}{|c|c|c|}
\hline & Employment ${ }^{(\mathrm{s})}$ & Land Use \\
\hline Construction & 1.9 & 5.9 \\
\hline Operation & 0.4 & $\mathrm{NQ}$ \\
\hline
\end{tabular}

(a) Construction is in employee years per megawatt capacity; operation is in employees per year per megawatt capacity.

(b) Construction is in total acres disturbed per megawatt capacity; operation is in acres disturbed per year per megawatt capacity.

$N Q=$ Not quantified.

\subsection{CONSTRUCTION}

The construction schedule for wind energy facilities, the employment schedule, and the land-use impacts during construction are discussed below.

\subsubsection{Schedule and/or Duration}

Several sources present a broad range of scheduling information as summarized in Table 11.2.

\subsubsection{Direct Employment Schedule}

Cunningham (1986) estimates that construction employment varies on the technology used. Two options of obtaining $80 \mathrm{MW}$ of capacity are examined. The first option uses 455 Flowind $170-\mathrm{kW}$ turbines, while the second uses 31 Boeing MOD-2 2.5-MW turbines. Work-force estimates for these two turbine options are shown in Table 11.3. 
TABLE 11.2. Construction Duration for Wind Energy Plants

\begin{tabular}{|c|c|c|c|}
\hline $\begin{array}{l}\text { Capacity } \\
\text { (MW) }\end{array}$ & $\begin{array}{c}\text { Construction } \\
\text { Duration } \\
\text { (months) } \\
\end{array}$ & $\begin{array}{l}\text { Months } \\
\text { per MW }\end{array}$ & Source \\
\hline 0.2 & 12 & 60.0 & NWPPC $1989 G$ \\
\hline 20 & 4 & 0.2 & BPA 1985 \\
\hline 20 & 6 & 0.3 & BPA 1985 \\
\hline 20 & 10 & 0.5 & BPA 1985 \\
\hline 20 & 16 & 0.8 & BPA 1985 \\
\hline 650 & $12-24$ & $0.02-0.04$ & OTA 1985 \\
\hline 80 & 12 & 0.15 & Cunningham 1986 \\
\hline 80 & 24 & 0.3 & Cunningham 1986 \\
\hline
\end{tabular}

IABLE 11.3. Construction Work-Force Requirements for Wind Energy Generators

\begin{tabular}{|c|c|c|c|c|c|}
\hline Turbine Type & Local & $\begin{array}{l}\text { Non- } \\
\text { Local }\end{array}$ & Iotal & $\begin{array}{c}\text { Employee } \\
\text { Years }\end{array}$ & $\begin{array}{l}\text { Emp loyee } \\
\text { Years } \\
\text { per MW }\end{array}$ \\
\hline Flowind $170 \mathrm{~kW}$ & 150 & 25 & 175 & 175 & 2.2 \\
\hline Boeing MOD-2 2.5 MW & 43 & 81 & 124 & 248 & 3.1 \\
\hline
\end{tabular}

ECO Northwest estimates that 25 construction employee-years would be required for a 50-MW facility, or 0.5 employee-years per MW (ECO Northwest et a). 1986).

The average of these three estimates is 1.9 employee years per MW capacity.

The Worldwatch Institute report (Flavin and Lenssen 1990) estimates that wind power generates 542 jobs per thousand gigawatt-hours annually, including construction and operation.

\subsubsection{Construction Land-Use Impacts}

Siting requirements for wind parks include the land immediately adjacent to each generator and other reserved land needed to ensure proper spacing between the generators. Blair, Jones, and Jones (1986) estimate the land-use impacts for the Boeing MOD-2 and the Flowind 170 described above, as well as 
for 259 DAF 6400 vertical-axis turbines (see Table 11.4). The averaged 1 anduse requirement for the three turbine types is 5.9 acres per MW capacity. This land is occupied by turbines, roads, utility lines, and other equipment dedicated to the maintenance and operation of the plant.

In addition, Bonneville has estimated that for every 4.5 to 6.1 acres of 1 and needed for each MW of capacity for a wind generator, another 113.6 to 233.1 acres must be reserved to space the generators. ${ }^{(8)}$ Most of this additional land in a wind park is available for compatible uses, such as livestock grazing, some types of agriculture, or photovoltaic power production.

IABLE 11.4. Acreage Requirements for Generator Types (acres)

$\begin{array}{lll}\text { Boeing } & \text { Flowind } & \text { DAF } \\ \text { MOD-2 } & 170 & \text { 6400 }\end{array}$

Permanent:

$\begin{array}{lccc}\text { Machine Foundations } & 6 & 4 & 2 \\ \text { Accessory Facilities } & 1 & 1 & 1 \\ \text { Access Roads } & 22 & 52 & 42 \\ \text { Total } & 29 & 57 & 45 \\ \text { Total Per-MW Capacity } & 0.36 & 0.71 & 0.56\end{array}$

Disturbed During Construction:

Clearing for Wind Access $55 \quad 60 \quad 55$

Machine Erection Areas $\quad 51 \quad 202 \quad 115$

$\begin{array}{llll}\text { Total } & 56 & 244 & 119\end{array}$

Total Per-MW Capacity $\quad 0.70 \quad 3.05 \quad 1.49$

Total Including Land Partially Obstructed by Guy Wires:

Total $\begin{array}{lll}56 & 752 & 617\end{array}$

$\begin{array}{llll}\text { Total Per-MW Capacity } & 0.70 & 9.4 & 7.7\end{array}$

(a) Personal communication from Nick Butler, Bonneville Power Administration, December 11, 1991. 


\subsection{OPERATION}

The employment impacts resulting from operation of a wind generator facility are discussed below.

\subsubsection{Direct Emplovment}

In addition to the operations employment impacts included in Flavin and Lenssen (1990) and the ones discussed above in Table 11.3, Cunningham (1986) estimates employment impacts for the 80-MW Cape Blanco facility shown in Table 11.5 below.

\subsubsection{Operation Land-Use Impacts}

The permanently disturbed land requirements are discussed in Section 11.1.3. Blair, Jones, and Jones (1986) also indicate significant potential for noise and visual impacts on residential areas.

TABLE 11.5. Operations Work-Force Requirements for Wind Energy Plants

\begin{tabular}{|c|c|c|c|c|}
\hline & Local & $\begin{array}{l}\text { Non- } \\
\text { Local }\end{array}$ & Iotal & $\begin{array}{l}\text { Total } \\
\text { per MW }\end{array}$ \\
\hline Flowind $170 \mathrm{~kW}$ & 18 & 2 & 20 & 0.25 \\
\hline Boeing MOD-2 2.5 MH & 25 & 25 & 50 & 0.62 \\
\hline Average & 22 & 14 & 35 & 0.4 \\
\hline
\end{tabular}




\subsection{NUCLEAR}

A summary of the impacts of the construction and operation of nuclear plants on employment and land-use is shown in Table 12.1. Sections 12.1 and 12.2 provide detailed discussions of how these impacts were determined.

IABLE 12.1. Resource Summary for Nuclear Plants

\begin{tabular}{|c|c|c|}
\hline & Employment ${ }^{(\theta)}$ & Land Use ${ }^{(b)}$ \\
\hline Construction & 1.8 & 3.5 \\
\hline Operation & 0.9 & NQ \\
\hline
\end{tabular}

(a) Construction is in employee years per megawatt capacity; operation is in employees per year per megawatt capacity.

(b) Construction is in total acres disturbed per megawatt capacity; operation is in acres disturbed per year per megawatt capacity.

NQ $=$ Not quantified.

\subsection{CONSTRUCTION}

The construction schedule for nuclear energy plants, the employment schedule, and the land-use impacts during construction are discussed below.

\subsubsection{Schedule and/or Duration}

Numerous sources offer figures on construction scheduling. These figures are presented in Table 12.2.

\section{TABLE 12.2. Construction Duration}

\begin{tabular}{cccl}
$\begin{array}{c}\text { Capacity } \\
\text { (MW) }\end{array}$ & $\begin{array}{c}\text { Ouration } \\
\text { (months) }\end{array}$ & $\begin{array}{c}\text { Months } \\
\text { per MW }\end{array}$ & \multicolumn{1}{c}{ Source } \\
\cline { 1 - 1 } 2,540 & 108 & 0.04 & BPA 1985 \\
1,250 & 60 & 0.05 & NWPPC 1989e \\
1,240 & 60 & 0.05 & NWPPC 1989e \\
1,000 & 132 & 0.13 & OTA 1985 \\
2,664 & 120 & 0.05 & Denver Research Inst 1982 \\
2,200 & 96 & 0.04 & Denver Research Inst 1982
\end{tabular}




\subsubsection{Direct Employment Schedule}

The Worldwatch Institute report (Flavin and Lenssen 1990) estimates 100 jobs per thousand gigawatt-hours per year. This figure includes both construction and operation.

The Council on Economic Priorities (1979) estimates the regional employment impacts of nuclear-generated electricity to be 0.22 to 0.51 labor years per GWh. Again, this includes both construction and operation.

Charles River Associates (1984) estimates that nuclear generation produces 29 jobs per million kWh supplied, or 254 jobs per MW capacity. This includes construction and operation over a 30-year period.

The study by Baechler, Fickeisen, and Hendrickson (1990) put the construction force for the 1,250-MW Washington Public Power Supply System Nuclear Plant (WNP)-1 plant at 2,000 to 3,000. This calculates to 1.6 to 2.4 employees per MW.

The Denver Research Institute (1982) provides employment estimates for two nuclear plants. These values are presented in Table 12.3.

IABLE 12.3. Employment Levels During Construction of Nuclear Plants

\begin{tabular}{|c|c|c|c|c|c|}
\hline \multirow[b]{2}{*}{ Plant } & \multirow{2}{*}{$\begin{array}{c}\text { Capacity } \\
(1,000 \mathrm{MW})\end{array}$} & \multirow{2}{*}{$\begin{array}{l}\text { Construction } \\
\text { Manhours } \\
\text { (thousands) } \\
\end{array}$} & \multirow{2}{*}{$\begin{array}{l}\text { Employee } \\
\text { Years } \\
\text { (per } M W \text { ) }\end{array}$} & \multicolumn{2}{|c|}{$\begin{array}{c}\text { Peak Construction } \\
\text { Employment }\end{array}$} \\
\hline & & & & (Total) & (per MW) \\
\hline Bellefonte & 2.66 & 45,000 & 8.4 & 4,350 & 1.6 \\
\hline San Onofre & 2.20 & 43,023 & 9.8 & 3,764 & 1.7 \\
\hline
\end{tabular}

Using the three sources that have separate construction estimates, an average of 1.6 to 1.9 employee years per MW capacity is obtained. Therefore, 1.8 employee years per $\mathrm{MW}$ is used.

\subsubsection{Construction Land-Use Impacts}

Baechler, Fickeisen, and Hendrickson (1990) estimate the total 1 and area required for a fuel cycle to support a 1,000-MW plant to be 113 acres or 0.11 acres per MW capacity. Only 13 acres is permanently dedicated, while 100 acres is temporarily committed. And 22 acres of the 113 is disturbed during construction. If all three of the Washington Public Power Supply System 
nuclear plants - WNP-1, WNP-2, and WNP-3 - were completed, Bonneville estimates indicate that 1.74 acres per MW of capacity would be occupied. (a)

The Office of Technology Assessment (OTA 1985) estimates a 1,000-MW plant requires 1,000 acres. This calculates to 1 acre per MW capacity.

The Northwest Power Planning Council (NWPPC 1990) has estimates for 1 and requirements for a 1,250-MW capacity light water reactor. These estimates are presented in Table 12.4.

IABLE 12.4. Acreage Requirements for a 1,250-MW Nuclear P1 ant

$\begin{array}{lcr} & \text { Land (acres) } & \text { Acres per } \\ \text { Site } & 200 & 0.16 \\ \text { Exclusion Area } & 7,260 & 5.81 \\ \text { Total } & 7,460 & 5.97\end{array}$

Averaging the OTA figure ( 1 acre per $M W$ ) and the NWPPC figure $(5.97$ acres per MW) gives a value of 3.5 acres per MW. Bonneville's estimate for the Washington nuclear plants falls within this range at 1.74 acres per MW. Because only these plants are under consideration by Bonneville, the 1.74 acres per MW figure will be used.

\subsection{OPERATION}

The employment and land-use impacts resulting from operation of a nuclear power plant are discussed below.

\subsubsection{Direct Employment}

Several sources (Flavin and Lenssen 1990; Charles River Associates 1984; and the Council on Economic Priorities 1979) provide estimates of employment for both construction and operation. These are cited in the discussion on construction employment impacts. The International Energy Agency (1989) estimates that labor accounts for $67 \%$ of the fixed $0 \& M$ costs at U.S. nuclear

(a) Estimates for Washington nuclear plants are taken from site drawings; estimates provided in personal communication from Kristina Rohe, Bonneville Power Administration, to Michael Baechler, Pacific Northwest Laboratory, December 13, 1991. 
plants. Using the 67\% figure and fixed 0\&M numbers from Bonneville (BPA 1985) and the NWPPC (1989e), and assuming nuclear operations salaries are the same as pulverized coal operations salaries (see the Appendix), estimates for direct employment are calculated. These calculations are presented in Table 12.5 .

TABLE 12.5. Employment Levels Required During Operation of a Nuclear Plant

\begin{tabular}{|c|c|c|c|c|}
\hline $\begin{array}{c}\text { Capacity } \\
(M W) \\
\end{array}$ & $\begin{array}{c}\text { Fixed 0\&M } \\
(1989 \$ / \mathrm{kW} / \mathrm{yr})\end{array}$ & $\begin{array}{c}\text { Labor 0\&M } \\
(1989 \$ / M W / y r)\end{array}$ & $\begin{array}{l}\text { O\&M Employment } \\
\text { per MW }\end{array}$ & Source \\
\hline 1,250 & 60.63 & 40,622 & 1.1 & NWPPC $1989 \mathrm{e}$ \\
\hline 1,240 & 61.12 & 40,950 & 1.1 & NWPPC $1989 \mathrm{e}$ \\
\hline 2,540 & 34.38 & 23,034 & 0.6 & BPA 1985 \\
\hline 1,677 & 47.49 & 31,821 & 0.9 & Average \\
\hline
\end{tabular}

\subsubsection{Qperation Land-Use Impacts}

Operations land-use impacts would consist of the land disturbed by fuel mining and processing facilities. No attempt was made to estimate the magnitude of this impact. 


\subsection{CONSERVATION}

Conservation is a fundamentally different option than any of the generating options discussed in the preceding sections. Conservation is obtained by retrofitting existing facilities and constructing new facilities that use energy more efficiently. There is no meaningful construction period aspect of a conservation option, nor is there any facility to operate, nor are there any land-use impacts. The discussion of conservation will therefore consist of a review of the literature on labor costs of various forms of conservation.

Raab (1987) conducted a survey of five weatherization firms in Eugene, Oregon, which accounted for half of the weatherization activity in the greater Eugene area. The average cost of installing floor insulation was $\$ 847$ (1989 dollars) for 1,500 square feet, of which $24.2 \%$, or $\$ 205$, went to labor. These figures were based on 5,925 installations of floor insulation by the five firms. The report states that other types of insulation have similar cost breakdowns. This report also states that $7.3 \%$ of the cost of conservation programs is commission; $2.8 \%$ is bonding and insurance; $12.3 \%$ is overhead; and $9.1 \%$ is profit. All of these categories could reasonably be expected to contain significant labor components: an individual is most likely earning the commissions, and individuals are providing the bonding and insurance, the overhead is paying for office staff and sales personnel, and the profit is going to the business owner. The $24.2 \%$ for labor should therefore be viewed as a lower bound, while an upper bound may be found by assuming that all of each of the above expenses goes to labor. This would give an upper bound of $56 \%$. Splitting the difference gives a reasonable estimate of $40 \%$. Charles River Associates (1984) states that most studies find that slightly less than $50 \%$ of the cost of conservation programs goes for labor; therefore, $40 \%$ seems a reasonable figure.

Bonneville (BPA 1990) provides estimates of the capital cost per kW for a number of conservation resources (see Table 13.1). A rough estimate of the employment impacts can be obtained by using the $40 \%$ labor portion discussed above, along with an estimate of average conservation worker salaries. 
TABLE 13.1. Employment Levels for Construction of Various Conservation Resources

\begin{tabular}{|c|c|c|c|c|}
\hline Resource & $\begin{array}{l}\text { Unit } \\
\text { Size } \\
\text { (MW) }\end{array}$ & $\begin{array}{l}\text { Capital Cost } \\
\left(1989 \$ / k^{\prime}\right)\end{array}$ & $\begin{array}{l}\text { Labor } \\
\text { Capital Cost } \\
(1989 \$ / \mathrm{kW})\end{array}$ & $\begin{array}{l}\text { Employee } \\
\text { Years } \\
\text { per MW } \\
\end{array}$ \\
\hline \multicolumn{5}{|l|}{ Residential Space Heat: } \\
\hline Existing $S F$ & 102 & 5,938 & 2,375 & 77.9 \\
\hline Existing MF & 36 & 5,669 & 2,268 & 74.3 \\
\hline New SF & 116 & 6,039 & 2,416 & 79.2 \\
\hline New MF & 32 & 6,189 & 2,476 & 81.2 \\
\hline New Manufactured & 96 & 4,191 & 1,676 & 55.0 \\
\hline \multicolumn{5}{|l|}{ Residential Appliances: } \\
\hline Refrigerators & 82 & 1,428 & 571 & 18.7 \\
\hline Freezers & 29 & 1,780 & 712 & 23.3 \\
\hline Water Heating & 258 & 1,383 & 553 & 18.1 \\
\hline \multicolumn{5}{|l|}{ Commercial: } \\
\hline Exist. Bldgs Disc. & 162 & 2,304 & 922 & 30.2 \\
\hline Exist. Bidgs Lost Opp. & 149 & 1,539 & 616 & 20.2 \\
\hline New Const Lost 0pp. & 317 & 1,493 & 597 & 19.6 \\
\hline Industrial: & 256 & 1,673 & 669 & 21.9 \\
\hline Agricultural: & 35 & 1,717 & 687 & 22.5 \\
\hline
\end{tabular}

Charles River Associates (1984) assumes the average conservation worker earns $\$ 30,500$, when adjusted to 1989 dollars.

For comparison, a report by Charles River Associates (1984) provides its own estimate of the employment impacts of conservation. The same report estimates that 2 employee years will be created in the region per 1 million kWh supplied. This figure includes investment and operating costs over 30 years, as well as the decrease in employment due to utilities receiving lower revenues. Converting kWh to MW of capacity provides an estimate of 17.5 employee years per MW capacity, a figure not inconsistent with the more specific values given above. 


\subsection{REFERENCES}

Baechler, M. C., D. H. Fickeisen, and P. L. Hendrickson. 1990. Environmental Effects and Mitigation for Energy Resources. PNL-SA-18087, prepared by the Pacific Northwest Laboratory for the Bonneville Power Administration, Portl and, Oregon.

Biosystems Analysis, Inc. 1984. Methods for Valuation of Environmental Costs and Benefits of Hydroelectric Facilities: a Case Study of the Sultan River Project. DOE/BP-266, Bonneville Power Administration, Portland, Oregon.

Blair, W. G. E., Jones and Jones. 1986. Cape Blanco Wind Farm Feasibility Study Technical Report Number 8: Land Use. DOE/BP-11191-8, Bonneville Power Administration, Portland, Oregon.

Bonneville Power Administration (BPA). 1985. Generating Resources Supply Curves. Bonneville Power Administration, Portland, Oregon.

Bonneville Power Administration (BPA). 1986. Comparative Electric Generation Study: Coal Gasification (Shell Gasification-Based Phasing Study). Bonneville Power Administration, Portiand, Oregon.

Bonneville Power Administration (BPA). 1987. Comparative Electric Generation Study: Coal-Fired Power Plants. Bonneville Power Administration, Portland, Oregon.

Bonneville Power Administration (BPA). 1988. Intertie Development and Use: Final Environmental Impact Statement Volume 1: Environmental Analyses. DOE/EIS-0125-F, Bonneville Power Administration, Portland, Oregon.

Bonneville Power Administration (BPA). 1990. 1990 Resource Program Technical Report. Bonneville Power Administration, Portland, Oregon.

California Energy Commission. 1983. Cumulative Impact Study of the Geysers KGRA: Public Service Impacts of Geothermal Development, Final Staff Report, State of California, Sacramento, California.

Charles River Associates. 1984. Final Report: Employment Effects of Electric Energy Conservation. CRA Report No. 721.01, prepared for the Bonneville Power Administration, Portland, Oregon.

Council on Economic Priorities. 1979. Jobs and Energy: the Employment and Economic Impacts of Nuclear Power, Conservation, and other Energy Options. Council on Economic Priorities, New York.

Cunningham, E. S. 1986. Cape Blanco Wind Farm Feasibility Study Technical Report Number 9: Socioeconomics. DOE/BP-11191-9, prepared by the Envirosphere Company for the Bonneville Power Administration, Portland, Oregon. 
Denver Research Institute (DRI). 1982. Socioeconomic Impacts of Power Plants. EA-2228, prepared for the Electric Power Research Institute, Palo Alto, California.

ECO Northwest. 1983. Final Report: Economic Analysis of the Environmental Effects of the Coal-Fired Electric Generator at Boardman, Oregon. Bonneville Power Administration, Portland, Oregon.

ECO Northwest, Shapiro and Associates, and Seton, Johnson, and 0de11, Inc. 1986. Estimating Environmental Costs and Benefits for Five Generating Resources. Technical Appendices: Description of Generic Generating Resources, Their Likely Significant Environmental Effects, and the Economic Value of Those Effects. Bonneville Power Administration, Portland, Oregon.

Flavin, C. and $N$. Lenssen. 1990. Beyond the Petroleum Age: Designing a Solar Economy. Worldwatch Paper 100, Worldwatch Institute, Washington, D.C.

Fluor Daniel, Inc. 1988. Development of Combustion Turbine Capital and Operating Costs. DOE/BP-63056-1, prepared for the Bonnevilie Power Administration, Portland, Oregon.

Geyer, J. D. 1988. "Economic Effects of Geothermal Development." Transactions, Vol. 12, Geothermal Resources Council.

International Energy Agency. 1989. Projected Costs of Generating Electricity from Power Stations for Commissioning in the Period 1995-2000. Organization for Economic Cooperation and Development, Nuclear Energy Agency, Paris, France.

Kaiser Engineers. 1986. Preconstruction Costs and Schedules for Comparative Electric Generation Study: Coal-Fired Plants. Prepared for the Bonneville Power Administration, Portland, Oregon.

Murdock, S. H. and F. L. Leistritz. 1979. Enerqy Development in the Western United States: Impact on Rural Areas. Praeger Publishers, New York.

Northwest Power Planning Council (NWPPC). 1989a. 1989 Supplement to the 1986 Northwest Conservation and Electric Power Plan, NWPPC 89-1, Volume 1 , Northwest Power Planning Council, Portland, Oregon.

Northwest Power Planning Council (NWPPC). 1989b. Staff Issue Paper 89-46: Solar Electric Resources. Northwest Power Planning Council, Portland, Dregon.

Northwest Power Planning Council (NWPPC). 1989c. Staff Issue Paper 89-45: Potential Cogeneration Resources in the Pacific Northwest. Northwest Power Planning Council, Portland, Oregon.

Northwest Power Planning Council (NWPPC). 1989d. Staff Issue Paper 89-44: Coal Fired Generating Resources. Northwest Power Planning Council, Portiand, Oregon. 
Northwest Power Planning Council (NWPPC). 1989e. Staff Issue Paper 89-43: Nuclear Resources. Northwest Power Planning Council, Portland, Oregon.

Northwest Power Planning Council (NWPPC). 1989f. Staff Issue Paper 89-41: Biomass Resources. Northwest Power Planning Council, Portland, Oregon.

Northwest Power Planning Council (NWPPC). 1989g. Staff Issue Paper 89-40: Wind Resources. Northwest Power Planning Council, Portland, Oregon.

Northwest Power Planning Council (NWPPC). 1989h. Staff Issue Paper 89-36: Geothermal Resources. Northwest Power Planning CounciT, Portland, Oregon.

Northwest Power Planning Council (NWPPC). 1990. Staff Issue Paper 90-1: New Resources: Supply Curves and Environmental Effects. Northwest Power Planning Counci1, Portland, Oregon.

Office of Technology Assessment (OTA). 1985. New Electric Power Technologies: Problems and Prospects for the 1990's. OTA-E-246, Office of Technology Assessment, U.S. Congress, Washington, D.C.

Raab, J. D. 1987. New Perspectives on Energy and Economic Development: a Qual itative and Quantitative Analysis. Bureau of Governmental Research and Service, University of Oregon, Eugene, Oregon.

Solar Energy Research Institute, 1989. Photovoltaics: Entering the 1990s. SERI/SP-220-3461, Solar Energy Research Institute, Golden, Colorado.

U.S. Department of Agriculture (USDA). 1979. Geothermal Leasing and Development: Gifford Pinchot National Forest Final Environmental Statement. USDA-FS-R6-FES-(ADM)79-1, U.S. Department of Agriculture, Washington, D.C.

U.S. DOE. 1981. National Implications of Solar Futures. A Technology Assessment of Sol ar Energy Systems. A TASE Project Report. D0E/EP-0025, U.S. Department of Energy, Washington, D.C.

U.S. Department of Energy (DOE). 1983. Energy Technology Characterizations Handbook. Environmental Pollution and Control Factors. DOE/EP-0093, U.S. Department of Energy, Washington, D.C. 
.

\author{
.
}


APPENDIX

DEVELOPMENT OF_ASSUMPTIONS 
APPENDIX

\section{DEVELOPMENT OF ASSUMPTIONS}

Tables A.1 through A.10 show the assumptions used by the authors in the analyses described in this report to determine impacts in terms of land use and employment as a result of the different energy-generating alternatives under consideration in the Bonneville Power Administration's Draft Resource Program Environmental Impact Statement (BPA 1991).

IABLE A.1. Converting to 1989 Dollars Using the Gross National Product Price Deflator

\begin{tabular}{ccc} 
Year & $\begin{array}{c}\text { GNP } \\
\text { Price } \\
\text { Deflator }\end{array}$ & $\begin{array}{c}\text { Multiplier } \\
\text { to Convert } \\
\text { to 1989 } \$\end{array}$ \\
\cline { 2 - 3 } 1970 & 42.0 & 3.01 \\
1971 & 44.4 & 2.84 \\
1972 & 46.5 & 2.72 \\
1973 & 49.5 & 2.55 \\
1974 & 54.0 & 2.34 \\
1975 & 59.3 & 2.13 \\
1976 & 63.1 & 2.00 \\
1977 & 67.3 & 1.88 \\
1978 & 72.2 & 1.75 \\
1979 & 78.6 & 1.61 \\
1980 & 85.7 & 1.47 \\
1981 & 94.0 & 1.34 \\
1982 & 100.0 & 1.26 \\
1983 & 103.9 & 1.22 \\
1984 & 107.8 & 1.17 \\
1985 & 111.0 & 1.14 \\
1986 & 113.8 & 1.11 \\
1987 & 117.4 & 1.08 \\
1988 & 121.3 & 1.04 \\
1989 & 126.3 & 1.00
\end{tabular}


TABLE A.2 Salary and Wage Estimates

\begin{tabular}{|c|c|c|c|c|c|c|}
\hline Source & Technology & Description & $\begin{array}{l}\text { Base } \\
\text { Year }\end{array}$ & $\begin{array}{l}\text { Annual } \\
\text { Salary } \\
\text { (Base \$) }\end{array}$ & $\begin{array}{l}\text { Hourly } \\
\text { Wage } \\
\text { (Base \$) }\end{array}$ & $\begin{array}{c}\text { Annual } \\
\text { Salary } \\
\text { (1989 \$) }\end{array}$ \\
\hline $\begin{array}{l}\text { Charles River } 1984 \\
\text { Charles River } 1984 \\
\text { Charles River } 1984 \\
\text { BPA } 1987 \\
\text { BPA } 1987 \\
\text { Murdock } 1979 \\
\text { Murdock } 1979 \\
\text { Cunningham } 1986 \\
\text { Cunningham } 1986 \\
\text { Average: }\end{array}$ & $\begin{array}{l}\text { Conserv } \\
\text { Conserv } \\
\text { Conserv } \\
\text { Pulv Coal } \\
\text { Pulv Coal } \\
\text { Coal } \\
\text { Nuclear } \\
\text { Wind } \\
\text { Wind }\end{array}$ & $\begin{array}{l}\text { Installation } \\
\text { Install-Non-Union } \\
\text { Install-Union } \\
\text { Non-Supervis } \\
\text { Supervis } \\
\text { Construct } \\
\text { Construct } \\
\text { Operations-F } \\
\text { Operations-B }\end{array}$ & $\begin{array}{l}1983 \\
1983 \\
1983 \\
1987 \\
1987 \\
1975 \\
1975 \\
1984 \\
1984\end{array}$ & $\begin{array}{l}\$ 25,000 \\
\$ 27,600 \\
\$ 37,500 \\
\$ 34,000 \\
\$ 51,000 \\
\$ 14,780 \\
\$ 14,780 \\
\$ 41,600 \\
\$ 40,000\end{array}$ & $\begin{array}{l}\$ 7.39 \\
\$ 7.39\end{array}$ & $\begin{array}{l}\$ 30,390 \\
\$ 33,550 \\
\$ 45,585 \\
\$ 36,578 \\
\$ 54,866 \\
\$ 31,479 \\
\$ 31,479 \\
\$ 48,739 \\
\$ 46,865 \\
\$ 39,948\end{array}$ \\
\hline
\end{tabular}

IABLE A.3. Operations Average by Technology

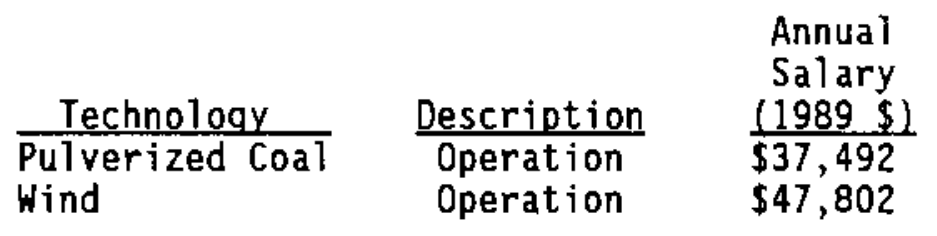

IABLE A.4. Construction Average by Technology

\begin{tabular}{|c|c|c|c|c|c|c|}
\hline Source & Technology & Description & $\begin{array}{l}\text { Base } \\
\text { Year }\end{array}$ & $\begin{array}{l}\text { Annual } \\
\text { Salary } \\
\text { (Base \$) }\end{array}$ & $\begin{array}{l}\text { Hourly } \\
\text { Wage } \\
\text { (Base \$) }\end{array}$ & $\begin{array}{c}\text { Annual } \\
\text { Salary } \\
\text { (1989 \$1 }\end{array}$ \\
\hline $\begin{array}{l}\text { Charles River } 1984 \\
\text { Charles River } 1984 \\
\text { Charles River } 1984 \\
\text { Murdock } 1979 \\
\text { Murdock } 1979 \\
\text { Average: }\end{array}$ & $\begin{array}{l}\text { Conserv } \\
\text { Conserv } \\
\text { Conserv } \\
\text { Coal } \\
\text { Nuclear }\end{array}$ & $\begin{array}{l}\text { Install } \\
\text { Install-Non-Union } \\
\text { Install-Union } \\
\text { Construct } \\
\text { Construct }\end{array}$ & $\begin{array}{l}1983 \\
1983 \\
1983 \\
1975 \\
1975\end{array}$ & $\begin{array}{l}\$ 25,000 \\
\$ 27,600 \\
\$ 37,500 \\
\$ 14,780 \\
\$ 14,780\end{array}$ & $\begin{array}{l}\$ 7.39 \\
\$ 7.39\end{array}$ & $\begin{array}{l}\$ 30,390 \\
\$ 33,550 \\
\$ 45,585 \\
\$ 31,479 \\
\$ 31,479 \\
\$ 34,496\end{array}$ \\
\hline
\end{tabular}

IABLEA.5. Actual Labor Fraction of O8M

$\begin{array}{lcc}\text { Source } & \text { Iechnology } & \begin{array}{c}\text { Labor } \\ \text { Percent of } \\ \text { Fixed O8M }\end{array} \\ \text { BPA 1986 } & \text { IGCC } & 56.4 \% \\ \text { Fluor } 1988 & \text { CT } & 71.5 \% \\ \text { IEA } 1989 & \text { Nuclear } & 67.0 \% \\ \text { IEA } 1989 & \text { COAL } & 29.0 \%\end{array}$


TABLE A.6. Development of Labor Fraction of 0\&M from Fixed O\&M and O\&M Employees per MW. Calculated average fixed $0 \& M$ per MW by technology (averages in Table A.7)

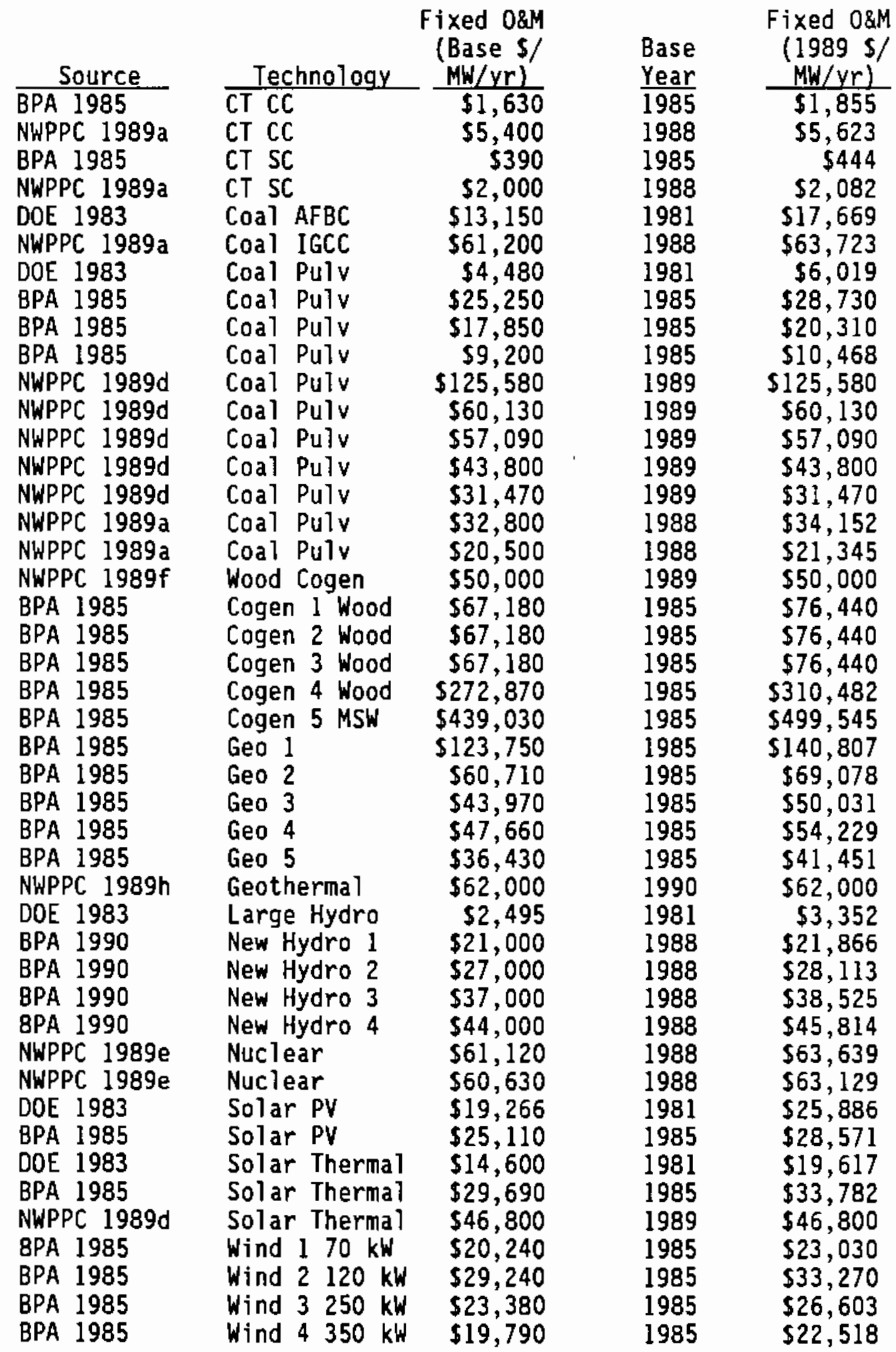


TABLE A.7. Average Fixed 0\&M by Technology (1989 \$/MW)

\begin{tabular}{lc} 
Technology & Average 08M \\
\cline { 2 - 2 } CT CC & $\$ 5,623$ \\
CT SC & $\$ 2,082$ \\
Coal AFBC & $\$ 17,669$ \\
Coal IGCC & $\$ 63,723$ \\
Coal Pulv & $\$ 39,918$ \\
Wood Cogen & $\$ 117,960$ \\
Cogen & $\$ 499,545$ \\
Geothermal & $\$ 69,600$ \\
Large Hydro & $\$ 3,352$ \\
New Hydro & $\$ 35,967$ \\
Nuclear & $\$ 63,384$ \\
Solar PV & $\$ 27,229$ \\
Solar Thermal & $\$ 33,400$ \\
Wind & $\$ 26,355$
\end{tabular}

TABLE A.8. Average 08M Employees per MW by Technology (averages in Table A.9)

\begin{tabular}{|c|c|c|}
\hline Source & Technology & per MW \\
\hline DOE 1981 & Coal AFBC & 0.22 \\
\hline BPA 1987 & Coal AFBC & 0.58 \\
\hline BPA 1987 & Coa] IGCC & 0.8 \\
\hline $\begin{array}{ll}\text { DOE } & 1981 \\
\text { BPA } & 1987\end{array}$ & Coal Pul & 0.22 \\
\hline $\begin{array}{ll}\text { BPA } & 1987 \\
\text { BPA } & 1987\end{array}$ & $\begin{array}{l}\text { Coal Pul } \\
\text { Coal Pul }\end{array}$ & $\begin{array}{l}0.57 \\
0.37\end{array}$ \\
\hline $\begin{array}{l}\text { BPA } 1987 \\
\text { BPA }\end{array}$ & Coal Pul & 0.17 \\
\hline CEC 1983 & Geothermal & 0.13 \\
\hline CEC 1983 & Geothermal & 0.11 \\
\hline DOE 1981 & Large Hydro & 0.05 \\
\hline DOE 1981 & Nuclear $81 \mathrm{~g}$. Wa & 0.16 \\
\hline $\begin{array}{l}\text { DOE } 1981 \\
\text { DOE } 1981\end{array}$ & Nuclear Pr. Wat & 0.16 \\
\hline Cunningham 1986 & Wind-Boeing & 0.63 \\
\hline Cunningham 1986 & Wind-Flo & 0.25 \\
\hline
\end{tabular}


TABLE A.9. Average 0\&M Employees per MW by Technology

\begin{tabular}{|c|c|}
\hline Technology & $\begin{array}{l}\text { Average } \\
\text { Employee }\end{array}$ \\
\hline $\begin{array}{l}\text { Coal AFBC } \\
\text { Coal IGCC } \\
\text { Coal Pul } \\
\text { Geothermal } \\
\text { Large Hydro } \\
\text { Nuclear Blg. W } \\
\text { Solar Thermal } \\
\text { Wind-Boeing }\end{array}$ & $\begin{array}{l}0.40 \\
0.80 \\
0.33 \\
0.12 \\
0.05 \\
0.16 \\
0.30 \\
0.44\end{array}$ \\
\hline
\end{tabular}

IABLE A.10. Labor Expenditures on 0\&M, Labor Portion

\begin{tabular}{|c|c|c|c|c|c|c|c|c|}
\hline \multirow[b]{2}{*}{ Technology } & \multirow{2}{*}{$\begin{array}{c}\text { Average } \\
\text { Fixed O\&M } \\
\end{array}$} & \multicolumn{2}{|c|}{ O\&M Labor } & \multirow{2}{*}{$\begin{array}{l}\text { O\&M Labor } \\
\text { Expenditur }\end{array}$} & \multicolumn{2}{|c|}{$0 \& M$} & \multicolumn{2}{|c|}{$0 \& M$} \\
\hline & & Fraction & ource & & Salary & Source & Employees & Source \\
\hline Coal Pul & $\$ 39,918$ & 0.29 & (a) & $\$ 11,576$ & $\$ 37,492$ & (b) & 0.33 & (b) (c) \\
\hline Coal AFBC & $\$ 17,669$ & 0.43 & (d) & $\$ 7,544$ & $\$ 37,492$ & (e) & 0.40 & (b) (c) \\
\hline Coal IGCC & $\$ 63,723$ & 0.56 & (f) & $\$ 35,940$ & $\$ 37,492$ & (e) & 0.80 & (b) \\
\hline Cogen - Wood & $\$ 117,960$ & 0.56 & (g) & $\$ 66,471$ & $\$ 37,492$ & (e) & 1.77 & (h) \\
\hline Cogen - MSW & $\$ 499,545$ & 0.56 & $(g)$ & $\$ 281,494$ & $\$ 37,492$ & (e) & 7.51 & (h) \\
\hline $\mathrm{CT}-\mathrm{CCCT}$ & $\$ 5,623$ & 0.72 & (i) & $\$ 4,020$ & $\$ 37,492$ & (e) & 0.11 & (h) \\
\hline $\mathrm{CT} \cdot \mathrm{SCCT}$ & $\$ 2,082$ & 0.72 & (j) & $\$ 1,489$ & $\$ 37,492$ & (e) & 0.04 & (h) \\
\hline Geothermal & $\$ 69,600$ & 0.56 & (g) & $\$ 39,219$ & $\$ 37,492$ & (e) & 0.12 & (k) \\
\hline New Hydro & $\$ 35,967$ & 0.56 & (g) & $\$ 20,267$ & $\$ 37,492$ & (e) & 0.05 & (c) \\
\hline Solar & $\$ 33,400$ & 0.56 & (g) & $\$ 18,821$ & $\$ 37,492$ & (e) & 0.30 & (c) \\
\hline Wind & $\$ 26,355$ & 0.56 & (g) & $\$ 14,851$ & $\$ 47,802$ & (I) & 0.44 & (l) \\
\hline Nuclear & $\$ 63,384$ & 0.67 & (a) & $\$ 42,467$ & $\$ 37,492$ & (e) & 0.16 & (c) \\
\hline Conservation & $\$ 0$ & 0.00 & & $\$ 0$ & $\$ 37,492$ & (e) & 0.00 & \\
\hline Average & $\$ 81,269$ & & & $\$ 38,351$ & & & 1.00 & \\
\hline
\end{tabular}
(a) International Energy Agency 1989
(b) BPA 1987
(c) DOE 1983
(d) Average of pulverized coal and IGCC.
(e) Assumed same as pulverized coal.
(f) BPA 1986
(g) Average of pulverized coal, AFBC, IGCC, CCCT, SCCT, and nuclear.
(h) Calculated as $O \& M$ labor expenditures divided by salary.
(i) Fluor Daniel Inc. 1988
(j) Assumed same as CCCT.
(k) California Energy Commission 1983
(I) Cunningham 1986 
.

.

. 